\title{
Trends in Antarctic Peninsula surface melting conditions from observations and regional climate modeling
}

\author{
N. E. Barrand, ${ }^{1}$ D. G. Vaughan, ${ }^{1}$ N. Steiner, ${ }^{2}$ M. Tedesco, ${ }^{2}$ P. Kuipers Munneke, ${ }^{3}$ \\ M. R. van den Broeke, ${ }^{3}$ and J. S. Hosking ${ }^{1}$ \\ Received 17 July 2012; revised 9 November 2012; accepted 1 December 2012; published 27 March 2013.
}

[1] Multidecadal meteorological station records and microwave backscatter time-series from the SeaWinds scatterometer onboard QuikSCAT (QSCAT) were used to calculate temporal and spatial trends in surface melting conditions on the Antarctic Peninsula (AP). Four of six long-term station records showed strongly positive and statistically significant trends in duration of melting conditions, including a 95\% increase in the average annual positive degree day sum (PDD) at Faraday/Vernadsky, since 1948. A validated, threshold-based melt detection method was employed to derive detailed melt season onset, extent, and duration climatologies on the AP from enhanced resolution QSCAT data during 1999-2009. Austral summer melt on the AP was linked to regional- and synoptic-scale atmospheric variability by respectively correlating melt season onset and extent with November near-surface air temperatures and the October-January averaged index of the Southern Hemisphere Annular Mode (SAM). The spatial pattern, magnitude, and interannual variability of AP melt from observations was closely reproduced by simulations of the regional model RACMO2. Local discrepancies between observations and model simulations were likely a result of the QSCAT response to, and RACMO2 treatment of, ponded surface water, and the relatively crude representation of coastal climate in the $27 \mathrm{~km}$ RACMO2 grid.

Citation: Barrand, N. E., D. G. Vaughan, N. Steiner, M. Tedesco, P. Kuipers Munneke, M. R. van den Broeke, and J. S. Hosking (2013), Trends in Antarctic Peninsula surface melting conditions from observations and regional climate modeling, J. Geophys. Res. Earth Surf., 118, 315-330, doi:10.1029/2012JF002559.

\section{Introduction}

[2] The Antarctic Peninsula (AP) has experienced rapid climate warming during the last 50 years with atmospheric temperature increases considerably greater than both the rest of Antarctica and the global mean [Intergovernmental Panel on Climate Change, 2007; Steig et al., 2009; Turner et al., 2005; Vaughan et al., 2003]. This warming has been accompanied by increases in ocean temperatures in the adjacent Bellingshausen [Meredith and King, 2005] and Weddell [Robertson et al., 2002] seas, reduction in seasonal sea-ice extent [Smith and Stammerjohn, 2001; Stammerjohn et al., 2008], and increases in both precipitation [Turner et al., 1997; van den Broeke et al., 2006] and snow accumulation [Thomas et al., 2008]. The mechanism proposed to explain this warming is a local strengthening of circumpolar westerly

\footnotetext{
${ }^{1}$ British Antarctic Survey, Natural Environment Research Council, Cambridge, UK.

${ }^{2}$ Cryospheric Processes and Remote Sensing Laboratory, City College of New York, CUNY, New York, NY, USA.

${ }^{3}$ Institute for Marine and Atmospheric Research, Utrecht University, Utrecht, Netherlands.

Corresponding author: N. E. Barrand, School of Geography, Earth and Environmental Sciences, University of Birmingham, Edgbaston, Birmingham, B15 2TT, UK. (n.e.barrand@bham.ac.uk)

(C2012. American Geophysical Union. All Rights Reserved. 2169-9003/13/2012JF002559
}

winds driven by changes in the summer Southern Hemisphere Annular Mode (SAM), predominantly in response to anthropogenic forcing [Marshall et al., 2006]. This causes advection of warmer maritime air masses over the orographic barrier of the Antarctic Peninsula, and consequent warming of the cooler continental climate as Fohn winds descend to the east [Orr et al., 2004; Marshall et al., 2006].

[3] As temperatures on the AP are frequently above $0^{\circ} \mathrm{C}$ in summer, surface snowmelt is widespread. Regional climate models suggest that as much as $66 \%\left(59 \mathrm{Gt} \mathrm{yr}^{-1}\right)$ of the total volume of Antarctic snowmelt occurs here [Kuipers Munneke et al., 2012a]. While much of this meltwater refreezes in the firn and does not leave the AP ice sheet, there are several important reasons for monitoring melt trends. Firstly, limited observations on the AP suggest that variations in summer melt drive substantial inter-annual variability in glacier mass balance [e.g., Rückamp et al., 2011; Smith et al., 1998]. The large volume of ice contained within the AP, combined with exceptional rates of climate warming and high sensitivity to temperature means that mass losses from both peripheral glaciers and the AP as a whole are significant [Hock et al., 2009; Ivins et al., 2011]. Projections of surface mass balance of AP peripheral glaciers indicate that mass losses are expected to continue for at least the next 100 years [Radic and Hock, 2011]. Secondly, the presence of meltwater has been implicated in a variety of glacier dynamic processes which may 


\section{BARRAND ET AL.: ANTARCTIC PENINSULA MELT TRENDS}

further accelerate the contribution of AP glaciers to sealevel rise. Increasing surface melt under future climate warming may trigger dynamic ice loss through acceleration of flow via enhanced basal lubrication. Thirdly, rising summer temperatures are suggested to have played a role in iceshelf breakup, most probably by providing the surface meltwater necessary for crevasse propagation [Scambos et al., 2000; van den Broeke, 2005]. Ice-shelf collapse has led to acceleration of flow of inland ice [e.g., De Angelis and Skvarca, 2003; Rignot et al., 2004; Rott et al., 2011; Scambos et al., 2004], and thus increased contribution to sea-level rise [e.g., Rignot et al., 2008; Shuman et al., 2011]. Finally, as firn densification is highly sensitive to rates of melt [e.g. Li et al., 2007; Helsen et al., 2008], changing melt patterns may be used to inform densification models which aid in the interpretation of ice sheet elevation changes [e.g. Ligtenberg et al., 2011].

[4] Examination of long-term temperature data from stations on the AP has shown statistically significant positive trends in the annual duration of melting (above-freezing) conditions [Vaughan, 2006]. That study was based on data from nine surface climate and automatic weather stations (AWS), from as far back as 1947 (Faraday/Vernadsky).
Since that study was published, new data have become available in the BAS/READER database (http://www.antarctica. ac.uk/met/READER/) extending existing records both forward (to the present, 2010/2011) and in some cases backward in time, and adding additional validated temperature data sets from a further 21 climate stations and AWS on the AP (Figure 1, Table 1). The existence of these new and updated observations (which in total number around three times those presented by [Vaughan, 2006], prompts a renewed analysis effort.

[5] In addition to in situ measurements, snowmelt extent in Antarctica (including the AP) has previously been successfully mapped using spaceborne passive microwave radiometers that detect the increase in microwave emissivity coincident with the appearance of liquid water in snow [Fahnestock et al., 2002; Kuipers Munneke et al., 2012a; Picard et al., 2007; Ridley, 1993; Tedesco, 2009; Tedesco and Monaghan, 2009; Torinesi et al., 2003]. It is important to mention here that while microwave measurements have commonly been used to detect melting conditions, liquid water may exist while the air temperature is below $0^{\circ} \mathrm{C}$, depending on other contributions to the energy balance. The term melting conditions in this context may

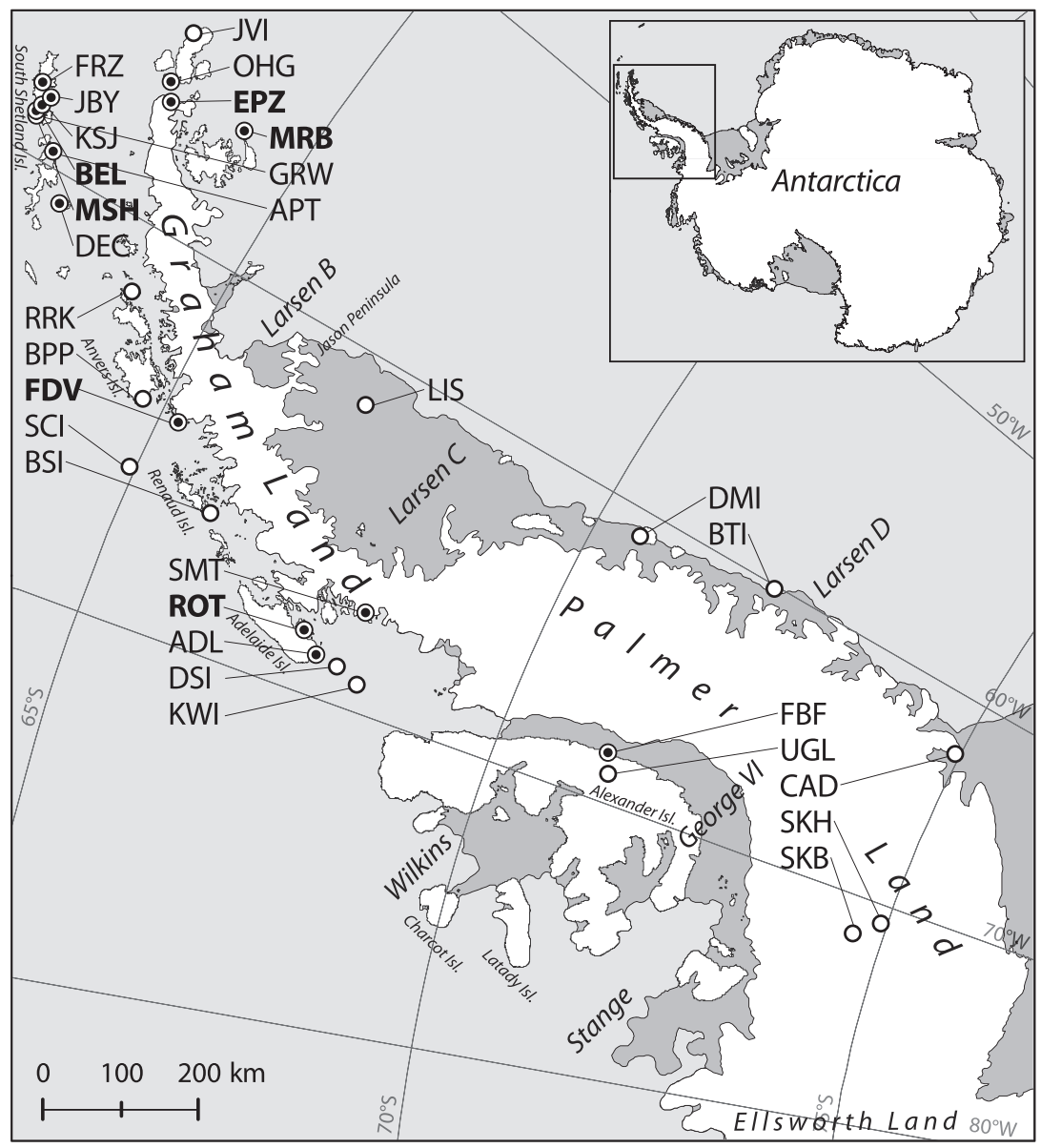

Figure 1. Location map of the Antarctic Peninsula and meteorological stations used in this study. Full names and details of each station are provided in Table 1. Climate stations are denoted with a bullseye symbol, automatic weather stations with an unfilled circle symbol, and stations for which long-term (>30 year) records exist are labelled in bold text. Major ice-shelf systems and other locations referred to in the main text are labelled in italic text. 
Table 1. List of Antarctic Peninsula Meteorological Data Sets Included in This Study ${ }^{\mathrm{a}}$

\begin{tabular}{|c|c|c|c|c|c|c|c|}
\hline Station & $\begin{array}{l}\text { Operated by } \\
\text { (Nation) }\end{array}$ & ID & Lat & Lon & $\begin{array}{l}\text { Height } \\
\text { (m.a.s.1) }\end{array}$ & $\begin{array}{c}\text { Data Available } \\
\text { (Years) }\end{array}$ & $\begin{array}{l}\text { Temporal } \\
\text { Resolution }\end{array}$ \\
\hline Ferraz & Brazil & FRZ & -62.08 & -58.38 & 20 & 1986-2010 & hourly \\
\hline Marsh & Chile & $\mathrm{MSH}$ & -62.18 & -58.98 & 10 & 1970-2009 & 3-hourly \\
\hline Bellingshausen & Russia & BEL & -62.20 & -58.93 & 16 & 1968-2009 & 6-hourly \\
\hline King Sejong & South Korea & KSJ & -62.22 & -58.75 & 11 & 1988-2000 & 6-hourly \\
\hline Great Wall & China & GRW & -62.22 & -58.97 & 10 & $1987-2005$ & 6-hourly \\
\hline Jubany & Argentina & JBY & -62.23 & -58.63 & 4 & 1985-2009 & 6-hourly \\
\hline Arturo Prat & Chile & APT & -62.50 & -58.68 & 5 & 1983-2003 & 3-hourly \\
\hline Deception & UK & DEC & -63.00 & -60.70 & 8 & 1959-1967 & 3-hourly \\
\hline Joinville Island $^{\mathrm{b}}$ & Brazil & JVI & -63.18 & -55.40 & 75 & 1997-2008 & hourly \\
\hline O’Higgins & Chile & $\mathrm{OHG}$ & -63.32 & -56.68 & 10 & 1988-2000 & 3-hourly \\
\hline Esperanza & Argentina & EPZ & -63.40 & -56.98 & 13 & 1960-2009 & 6-hourly \\
\hline Racer Rock ${ }^{b}$ & USA & RRK & -64.07 & -61.61 & 17 & 1990-2001 & 3-hourly \\
\hline Marambio & Argentina & MRB & -64.23 & -56.72 & 198 & 1971-2009 & 6-hourly \\
\hline Bonaparte Point ${ }^{b}$ & USA & $\mathrm{BPP}$ & -64.78 & -64.07 & 8 & $1992-2010$ & 3-hourly \\
\hline Santa Claus Island $^{\mathrm{b}}$ & USA & SCI & -64.96 & -65.67 & 25 & $1995-2000$ & 3-hourly \\
\hline Faraday/Vernadsky & UK/Ukraine & FDV & -65.25 & -64.27 & 11 & $1947-2010$ & hourly \\
\hline Biscoe Island $^{\mathrm{b}}$ & Brazil & BSI & -66.00 & -66.13 & 20 & 1998-2004 & hourly \\
\hline Larsen ice-shelf ${ }^{b}$ & UK & LIS & -67.02 & -61.52 & 43 & $\begin{array}{l}\text { 1986-1987, } \\
1995-2010\end{array}$ & 3-hourly \\
\hline Rothera & UK & ROT & -67.57 & -68.52 & 32 & 1976-2010 & hourly \\
\hline Adelaide Island & UK & ADL & -67.80 & -68.90 & 26 & $1962-1975$ & 3-hourly \\
\hline Dismal Island ${ }^{\mathrm{b}}$ & USA & DSI & -68.09 & -68.83 & 10 & $2001-2003$ & 3-hourly \\
\hline San Martin & Argentina & SMI & -68.12 & -67.13 & 4 & $2007-2008$ & 3-hourly \\
\hline Kirkwood Island ${ }^{\mathrm{b}}$ & USA & KWI & -68.34 & -69.01 & 30 & $2001-2003$ & 3-hourly \\
\hline Dolleman Island ${ }^{\mathrm{b}}$ & USA & DMI & -70.58 & -60.92 & 396 & 1986-1988 & 3-hourly \\
\hline Fossil Bluff & UK & $\mathrm{FBF}$ & -71.32 & -68.28 & 250 & 1999-2003 & hourly \\
\hline Uranus Glacier ${ }^{\mathrm{b}}$ & USA & UGL & -71.36 & -68.80 & 753 & $\begin{array}{l}1986-1990 \\
1992-2002\end{array}$ & 3-hourly \\
\hline Butler Island $^{\mathrm{b}}$ & UK & BTI & -72.20 & -60.17 & 115 & 1986-2010 & 3-hourly \\
\hline Sky-Blu ${ }^{b}$ & UK & SKB & -74.80 & -71.50 & 1556 & $\begin{array}{l}\text { 1999-2003, } \\
2009-2010\end{array}$ & 3-hourly \\
\hline $\mathrm{Ski}-\mathrm{Hi}^{\mathrm{b}}$ & USA & SKH & -74.98 & -70.77 & 1395 & 1994-1998 & 3-hourly \\
\hline Cape Adams ${ }^{b}$ & USA & CAD & -75.01 & -62.53 & 25 & 1989-1992 & 3-hourly \\
\hline
\end{tabular}

${ }^{a}$ Locations are displayed in Figure 1. Records are from land surface climate stations, except where marked.

${ }^{\mathrm{b}}$ Automatic weather station, AWS.

therefore refer to either snow that is actively melting or liquid water from previous melt that is subsequently refreezing.

[6] Melt extent alone may not be the most useful measure of summer melt on the smaller glaciers and ice caps of the northern AP, as almost all elevations of these regions experience melt every year. Summer melt duration is likely to be a more suitable index for this region, as strong correlation with annual positive degree day melting totals have been shown for similar glacier systems within the Arctic [e.g., Wang et al., 2005]. A similar measure, the cumulative melting surface or melt index (the product of melt duration and area) has also been shown to be a useful climatic indicator [e.g., Tedesco, 2009; Tedesco and Monaghan, 2009; Zwally and Fiegles, 1994]. A difficulty of the use of passive microwave data is that coarse spatial resolution $(\sim 25 \mathrm{~km})$ hinders its usefulness over the complex topography of the coastal, island, and northern sectors of the AP. In contrast to the low resolution of passive microwave radiometers, Ku-band scatterometer data from QuikSCAT (QSCAT, [Long and Hicks, 2010] has previously been used to map melt extent and duration at very high spatial (up to $2.225 \mathrm{~km}$ ) and temporal (daily) resolution in both the Arctic [e.g., Sharp and Wang, 2009; Rotschky et al., 2011; Wang et al., 2005; Wang et al., 2007] and Antarctic [e.g., Trusel et al., 2012; Steiner, 2012].

[7] The development of climate models with the ability to simulate the timing and duration of summer snowmelt is key to accurately projecting future glacier change [e.g., Machguth et al., 2009; Radic and Hock, 2006; Van de Wal and Wild, 2001; Zhang et al., 2007] and for capturing variations and feedbacks of high-latitude climate systems [e.g., Brown and Mote, 2009; Roesch, 2006]. However, validation of regional model output in Antarctica is difficult owing to the scarcity of surface observations, particularly inland of coastal stations. Both the small size and orography of the AP, combined with its complex melt dynamics, provide a considerable challenge for regional climate models. The availability of in situ and spaceborne observations of melting conditions provides an excellent opportunity for comparison with melt indices calculated from simulations of regional models.

[8] In this study, three principle analyses were performed: (1) Updated temperature data from all 30 climate stations and AWS (Figure 1) were analysed to determine long-term (multidecadal) trends in the annual duration of melting (above-freezing) conditions. This analysis provides quantification of the impact of recent rapid climate change on melting on the AP. (2) Enhanced resolution scatterometer data from QSCAT were used to detect melt throughout the AP, and to determine dates of melt onset and trends in melt duration and melt index for the period 1999-2009. These results provide a synoptic view of summer climate variability over ice-covered regions of the AP far removed from climate stations and AWS and may provide a basis for upscaling sparse 
measurements of glacier mass balance to the regional ice extent. Finally, (3) both in situ and spaceborne observations were compared to melt trends calculated from simulations of the regional climate model RACMO2, two-way coupled to a multi-layer snow model [Ettema et al., 2010]. The three analyses combine to provide long-term temporal trends in melting conditions, high-resolution, spatially representative melt climatologies, and a detailed assessment of the ability of a state-of-the-art regional model to simulate melting in the Antarctic Peninsula.

\section{Data and Methods}

\subsection{Trends in Positive Degree Days}

[9] Following the approach of Vaughan [2006], trends in the duration of melting conditions were derived by calculating annual positive degree day (PDD) sums (the integral in kelvin days over the course of a year of the excess of temperature above the melting point, $\left.273.15 \mathrm{~K}, 0^{\circ} \mathrm{C}\right)$. For each station record (Table 1), PDD sums $\left(\phi_{n}\right)$ were calculated for each austral melt season where data were available, $n$, using $i$ measurements, such that

$$
\begin{aligned}
& \phi_{n}=\sum_{i=\text { June } 22, \text { year } n-1}^{i=\text { June } 21, \text { year } n} T_{i}\left(t_{i+1}-t_{i}\right) \alpha\left(T_{i}\right) \\
& \text { where, } \alpha\left(T_{i}\right)=1 \text {, if } T_{i}>0^{\circ} \mathrm{C} \\
& \alpha\left(T_{i}\right)=0, \text { if } T_{i}<0^{\circ} C
\end{aligned}
$$

where $T_{i}$ is the station temperature in ${ }^{\circ} \mathrm{C}, t_{i}$ is time expressed in days (or fractions of days), and $\alpha$ is a binary function expressing whether or not melt will occur. Data from verified, shielded temperature sensors at the highest temporal resolution were used and records that were missing more than a total of seven days in any given year were discarded from the analysis. The use of 6-hourly, 3-hourly, and hourly temperature data, where available (see Table 1), provides a more sensitive evaluation of the potential for melt than analysis based on coarser temporal resolution averaged observations. Biases between PDD sums calculated from hourly and lower resolution temperature data (3-hourly and 6-hourly averages) were small ( $<12 \mathrm{~K}$ d for Rothera station, between 1976-2010). Although surface snowmelt is not directly proportional to air temperature due to non-linear interactions between components of the surface energy balance, the PDD approach is often used due to relatively modest data requirements (appropriate here given the constraints of our input data, $T_{i}$ only) and the recognized and robust empirical relationship between melt and air temperatures [e.g., Ohmura, 2001; Hock, 2005]. This relationship has been shown for glaciers on Livingstone Island in the Antarctic Peninsula [Jonsell et al., 2012], although [Kuipers Munneke et al., 2012b] note that calculations from Larsen C ice shelf based only on temperatures measured well above the snow surface may underestimate total melt. Trends in time-series of $\phi_{n}$ were calculated within 95\% confidence intervals using a minimisation of squared deviations (leastsquares) approach. Temporal autocorrelation was accounted for by estimating lag-1 autocorrelation within each time-series and adjusting standard errors by the effective sample size [e.g., Santer et al., 2000].

\subsection{Melt Detection From Satellite Data}

\subsubsection{QSCAT Enhanced Resolution Imagery}

[10] The basis for detection of melt from QSCAT data is the abrupt and significant reduction in microwave backscatter caused by the presence of liquid water in near surface snow and firn layers [Nghiem et al., 2001; Ulaby et al., 1986; Wang et al., 2005, 2007; Sharp and Wang, 2009]. The SeaWinds scatterometer on QSCAT made dual polarization measurements of backscatter (normalized radar cross section, $\sigma^{0}$ ) between June 1999 and November 2009 using a conically scanning antenna operating at $\mathrm{Ku}$-band $(13.4 \mathrm{GHz})$ frequency. SeaWinds $\sigma^{0}$ measurements were made at horizontal- and vertical-polarization using inner and outer beams at incidence angles of $46^{\circ}$ and $54.1^{\circ}$, corresponding to $1400 \mathrm{~m}$ and $1800 \mathrm{~m}$ wide elliptical swath footprints, respectively. An onboard range-doppler processor obtained 12 measurements per footprint, approximately $4-6 \mathrm{~km}$ long and $20 \mathrm{~km}$ wide (termed 'slices'). The summed measurements of the 8 centre slices have an effective resolution of $\sim 15 \mathrm{~km}$ by $25 \mathrm{~km}$. However, due to its orbit geometry and wide swath, QSCAT observed the polar regions multiple times each day, allowing reconstruction of surface backscatter at much higher resolution. By combining multiple passes within the Scatterometer Image Reconstruction (SIR) algorithm [Early and Long, 2001; Long and Hicks, 2010], enhanced resolution backscatter images are available for the polar regions for the full QSCAT observational period. Melt trends were derived by analysing daily, enhanced resolution, slice-based SIR images with a nominal pixel size of $2.225 \mathrm{~km}$ and an estimated effective resolution of $\sim 5 \mathrm{~km}$ [Long and Hicks, 2010; Steiner, 2012]. Since melting was most likely to take place during the day, midday-afternoon local time-of-day descending pass (horizontal polarization) images were used. These data have the additional advantage of improved spatial resolution $(2.225 \mathrm{~km})$ over vertical polarization images $(4.45 \mathrm{~km})$ [Long and Hicks, 2010]. All data are available for download from the Brigham Young University (BYU) NASA Scatterometer Climate Record Pathfinder URL (http://www.scp.byu.edu/).

\subsubsection{Melt Detection and Thresholding}

[11] As previously noted, the concept of microwave melt detection is based on the strong impact of even small amounts of liquid water on the electrical properties of snow at microwave frequencies. A dry $\left(<0^{\circ} \mathrm{C}\right)$ winter snowpack is easily penetrated by microwaves such that scattering from the air/snow interface can be neglected [e.g., Kunz and Long, 2006; Rott et al., 1993]. The microwave backscatter response in winter is therefore a function of volume scattering, or scattering from individual snow grains and internal layers in the snowpack [Ulaby et al., 1986]. During periods of melt the largest change in electrical properties occurs in the imaginary part of the dielectric constant, which can increase by more than an order of magnitude following the introduction of only $0.5 \%$ liquid moisture [Ulaby et al., 1986]. The effects of liquid water in a snowpack include increased microwave absorption, reduced penetration depth and subsurface scattering, and consequently a large decrease in $\sigma^{0}$ [Ashcraft and Long, 2006; Ulaby et al., 1986; Wang et al., 2005]. Backscatter (normalized radar cross section, $\sigma^{0}$ ) may also increase during periods of refreezing, but will fall again once snowmelt resumes. On the AP, there is close correspondence between the timing of positive $T_{i}$ and large reductions in $\sigma^{0}$ (e.g., Figure 2). 
[12] For this study, melt was defined on a pixel-by-pixel basis as being present (melting day, $\mathrm{MD}=1$ ) or absent $(\mathrm{MD}=0)$ using an austral winter mean normalized backscatter $\left(\sigma^{0}\right)$ threshold approach [e.g., Ashcraft and Long, 2006; Steiner, 2012; Trusel et al., 2012], such that:

$$
\begin{aligned}
& M D=1, \text { if } \sigma^{0}<\left(\overline{\sigma_{w}^{0}}-b\right) \\
& M D=0, \text { if } \sigma^{0} \geq\left(\overline{\sigma_{w}^{0}}-b\right)
\end{aligned}
$$

where $\sigma^{0}$ is the daily pixel backscatter, $\overline{\sigma_{w}^{0}}$ is the austral winter (JJA) mean pixel backscatter preceding each melt season, and $b$ is a threshold constant, with the value 3 , describing the amount of backscatter reduction necessary for a day to be classified as having melt. This fixed-threshold approach identifies 'wet' snowpack conditions based on the absolute difference in observed backscatter magnitude from a reference 'dry' state [e.g Ashcraft and Long, 2006; Trusel et al., 2012]. The $3 \mathrm{~dB}$ backscatter threshold is based on the expected $\mathrm{Ku}$-band response to a $10 \mathrm{~cm}$ surface layer of snow having a $1 \%$ liquid water content, simulated with a physically-based melt event model [Ashcraft and Long, 2006]. Ashcraft and Long [2006] also found that the $\sigma^{0}$ threshold approach performed well in comparison to other melt detection methods, particularly in eliminating unnatural phenomena, and has wide applicability to different snow and ice facies types. Other recent studies have used similar constant values [e.g., Rotschky et al., 2011; Steiner, 2012; Wang et al., 2007], and have successfully described $94 \%$ of continental Antarctic melting with a similar approach [Trusel et al., 2012].

[13] Persistent (or multi-day) melting was determined by eliminating sporadic melt events and possible 'false-starts' in melt by removing periods of less than 3 continuous days from the record [e.g., Tedesco et al., 2007; Wang et al., 2005]. For each pixel, the dates of melt onset and freezeup were defined as the first melt day and the day following the final melt day. Melt onset dates (in units of day of melt year) were defined after 'Jan-1-Year-1', where 'Year 1' was the year of December in the DJF melting season and are labelled by their second year (i.e., summer 1999-2000

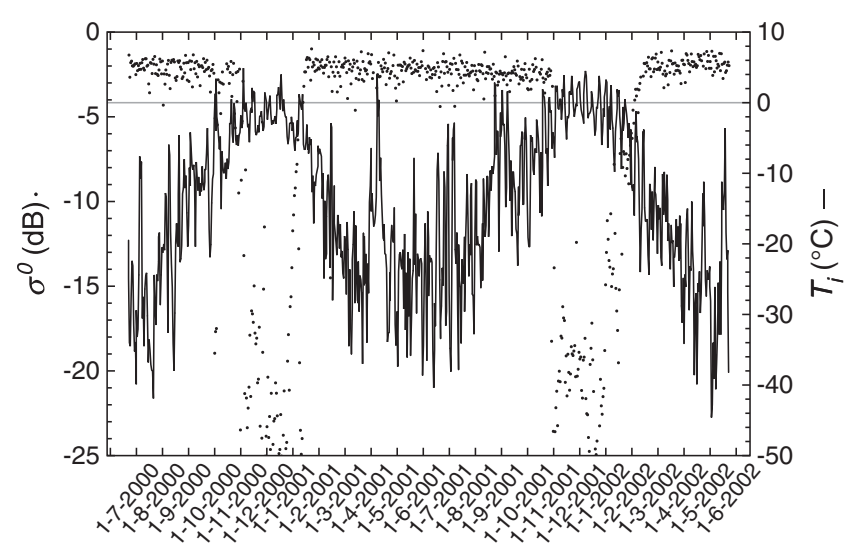

Figure 2. Time-series of daily midday-afternoon QSCAT $\sigma^{0}$ (dots) and 3-hourly surface air temperature (solid line) during 2000-2001 at Larsen ice-shelf (LIS). is 2000). Over the full QSCAT observational record there is good qualitative agreement between periods of reduced $\sigma^{0}$, positive $T_{i}$, and the timing of identified melt days (e.g., Figure 3). Linear regression between melt days identified from QSCAT pixels $\left(\mathrm{MD}_{\sigma^{0}}\right)$ and positive air temperature days from all coincident station records on the AP $\left(\mathrm{MD}_{T_{i}}\right)$ quantitatively confirms this relationship $\left(\mathrm{MD}_{T_{i}}=1.61\right.$ $\mathrm{MD}_{\sigma^{0}}-9$ days, $\mathrm{r}^{2}=0.65, \mathrm{p}$ value $<0.05$, standard error $=12.6$ days). Stronger correlations were found between $\mathrm{MD}_{\sigma^{0}}$ and $\mathrm{MD}_{T_{i}}$ at non-coastal stations (LIS, $\mathrm{r}^{2}=0.88 ; \mathrm{FBF}, \mathrm{r}^{2}=0.78$, UGL, $\mathrm{r}^{2}=0.81$ ), suggesting that the positive temperature melt threshold is appropriate and the abundance of coastal weather stations in the AP is likely the cause of the overall lower correlation value (due to contaminated melting signatures from changes in ocean conditions within the pixel footprint of coastal weather stations).

\subsubsection{Melt Extent}

[14] To accurately determine melt extent and index, QSCAT data were delineated at AP ice shelf margins and coastline (including islands) by clipping to the Moderateresolution Imaging Spectroradiometer (MODIS) Mosaic of Antarctica (MOA) [Haran et al., 2006] mask. As MOA was constructed from MODIS orbit swaths acquired between 20 November 2003 and 29 February 2004 [Haran et al., 2006], contemporaneous ice-shelf coastlines within the QSCAT observational period were amended both before and after these dates using published ice-shelf extents [Cook and Vaughan, 2010]. Ice-shelf boundaries were amended prior to 2003 at Larsen A and B, Wordie, and Wilkins ice shelves, and then post-2004 accounting for documented further retreats of Larsen B and Wilkins ice shelves [Cook and Vaughan, 2010]. Therefore, while maps of AP melt anomalies were produced for the present day (2010) ice extent, values of melt extent and index were adjusted to include all major changes to iceshelf fronts during the QSCAT era (between 1999 and 2009).

\subsection{Simulated Melt in the Regional Model RACMO2}

[15] Trends in melting conditions (melt onset date, extent, duration, and index) were also derived from simulations of the Royal Netherlands Meteorological Institute (KNMI) Regional Atmospheric Climate Model RACMO2. RACMO2 combines a description of atmospheric dynamics from the High Resolution Limited Area Model (HIRLAM), with the physical processes of the European Centre for MediumRange Weather Forecasts (ECMWF) global model. Melt indices for the AP were processed from model runs extending over the entire Antarctic continent at $27 \mathrm{~km}$ horizontal grid spacing [Kuipers Munneke et al., 2012a], with forcing at the lateral boundaries over the Southern Ocean from ERAInterim reanalysis data (from 1979-2010) [Dee et al., 2011]. Further details of the atmospheric component of RACMO2, which has been shown to be capable of realistically simulating near-surface temperature and wind climatologies in Antarctica, are provided by Lenaerts et al. [2012]. In order to accurately simulate surface melt, RACMO2 is two-way coupled to a multi-layer surface and sub-surface snow model (including a microphysical parameterization of snow albedo) which uses net surface energy fluxes to calculate melt, percolation, refreezing and meltwater runoff [Ettema et al., 2010; Kuipers Munneke et al., 2011].

[16] To facilitate comparison with spaceborne observations, melt days were computed from 3-hourly RACMO2 fields 


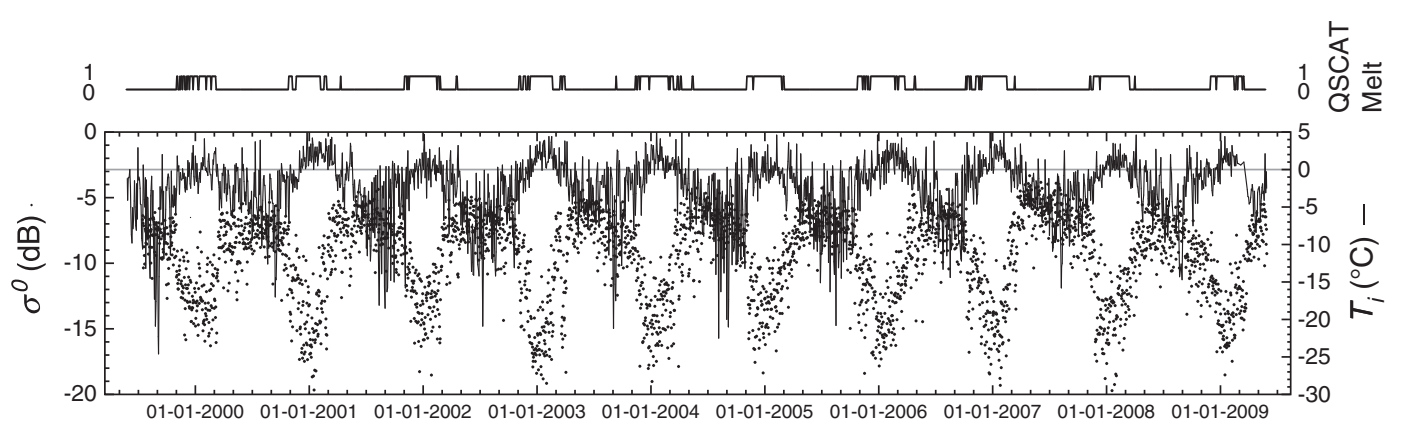

Figure 3. Time series of daily midday-afternoon QSCAT $\sigma^{0}$ (dots) and hourly surface air temperature (solid line) for the full QSCAT observational period (1999-2009) at Faraday Vernadsky (FDV). QSCAT-derived melt binary (melt present 1 , melt absent 0 ) is also shown.

using the percentage liquid water content of the uppermost metre of snow (rather than the total melt flux), and periods of less than 3 consecutive melt days were removed from the record. Melt was defined in RACMO2 using a $0.4 \mathrm{~mm}$ water equivalent (w.e.) threshold; that is, each pixel was considered to be melting when $0.4 \mathrm{~mm}$ or more of water was present in the uppermost metre of the snowpack. This value was obtained by minimising the RMS difference between continental-wide melt index from RACMO2 and passive microwave satellite measurements between 1979-2011 [Kuipers Munneke et al., 2012a]. In addition, the $0.4 \mathrm{~mm}$ threshold is in broad agreement with computations from a microwave radiative transfer model [Tedesco et al., 2007]. The minimisation procedure used to generate this threshold, however, implies that only the interannual variability of RACMO2 melt index can be compared with QSCAT satellite observations, not its absolute value.

\section{Results and Discussion}

\subsection{Variability in Melt Duration From In Situ Observations}

[17] Analysis of long-term AP climate station and AWS temperature data shows strong interannual variability and positive trends in annual PDD sums (Table 2, Figure 4). Of the six records where time series were of sufficient length to derive long-term trends, four (BEL, EPZ, MRB, FDV) showed strongly positive and statistically significant increases in $\phi_{n}$ (Table 2). These trends represent a considerable multidecadal increase in the annual duration of melting conditions on the AP. At BEL, the $\phi_{n}$ trend was $1.9 \pm 1.1 \mathrm{~K} \mathrm{~d} \mathrm{yr}^{-1}$, representing a $48 \%$ increase in the annual average PDD sum over the 41 year station record. The trend is less positive than

Table 2. Annual Trends in Positive Degree Day Sums for Stations on the Antarctic Peninsula for Which Long-Term Records Exist ${ }^{\mathrm{a}}$

\begin{tabular}{lccc}
\hline Station & $\begin{array}{c}\phi_{n} \text { Trend } \\
(\mathrm{K} \mathrm{d} \text { per year) }\end{array}$ & Significance & $\begin{array}{c}n \\
\text { (years) }\end{array}$ \\
\hline Bellingshausen & $1.90 \pm 1.10$ & $<1 \%$ & 41 \\
Esperanza & $3.40 \pm 1.19$ & $<1 \%$ & 42 \\
Marambio & $2.51 \pm 1.10$ & $<1 \%$ & 37 \\
Faraday/Vernadsky & $1.38 \pm 0.54$ & $<1 \%$ & 63 \\
Marsh & $-0.65 \pm 0.97$ & $15 \%$ & 37 \\
Rothera & $0.95 \pm 1.27$ & $19 \%$ & 34 \\
\hline
\end{tabular}

${ }^{a}$ Long-term records are defined as those $<30$ years in length. Uncertainties in the trends are quoted at the $95 \%$ confidence level. the $2.7 \pm 1.3 \mathrm{~K} \mathrm{~d} \mathrm{yr}^{-1}$ derived from 34 years of observations [Vaughan, 2006], due to 6 of the 7 melt seasons since 2003 having PDD sums below the long-term mean (see Figure 4). Similarly, the earlier trend at ROT $\left(1.8 \pm 1.7 \mathrm{~K} \mathrm{~d} \mathrm{yr}^{-1}\right.$ from 1977-2004 [Vaughan, 2006] is now no longer significant (Table 2), as all 7 melt years since 2004 have PDD sums below the long-term mean. At MSH and ROT (included in Table 2 for completeness), trends were within the range of uncertainties and of low statistical significance. Following the inclusion of an additional 8 years of data, the trend from the longest duration station record, FDV (1948-2011, $n=63)$, was unchanged $\left(1.4 \pm 0.5 \mathrm{~K} \mathrm{~d} \mathrm{yr}^{-1}\right)$ although uncertainty was reduced. The trendline of this time series shows a near doubling $(95 \%$ increase) in annual average PDD sums since 1948.

[18] The largest positive trends in $\phi_{n}$ were at EPZ and MRB, two stations on the east side of the AP (see Figure 1). As both mean annual air temperatures $(\bar{T})$ and $\phi_{n}$ at these stations are strongly correlated $\left(\mathrm{r}^{2}=0.92\right.$ and 0.83 , respectively, $n=34$ ), the trends are likely to be representative of the wider area of the northeastern AP. These strong positive trends in the duration of melting conditions are consistent with documented enhanced warming on the east side of the AP [Marshall et al., 2006; Orr et al., 2004]. Similarly, good correlation exists between $\bar{T}$ and $\phi_{n}$ at FDV and ROT $\left(\mathrm{r}^{2}=0.87\right.$ and 0.55 , respectively, $\left.n=34\right)$, suggesting that trends may be widespread on both sides of the AP [e.g., Vaughan, 2006].

[19] An additional $24 T_{i}$ station records were used to derive $\phi_{n}$ time-series that were too short to determine trends of any interpretable statistical significance (Table 1, Figure 4). Data from all 30 climate station and AWS observations were however utilized to examine the relationship between $\bar{T}$ and $\phi_{n}$ for the entire AP (Figure 5). While there is a reasonable correlation between all $\bar{T}$ and $\phi_{n}$ observations $\left(\phi_{n}=383 \mathrm{e}^{0.22 \bar{T}}\right.$, $\left.\mathrm{r}^{2}=0.65\right)$, stronger correlations were found when separating station measurements from the east and west sides of the AP $\left(r^{2}=0.80\right.$ and 0.73 , respectively, for full regression equations see Figure 5). The difference between curves representing station data from the east and west sides of the peninsula is due to the effect on mean annual air temperatures of colder winter temperatures in the continental climate of the east, compared to the warmer, wetter maritime climate of the west. The equations may be used to parameterise a calculation of $\phi_{n}$ spatially, using maps of $\bar{T}$ (from interpolation of in situ measurements or microwave brightness temperatures), to calculate total 
BARRAND ET AL.: ANTARCTIC PENINSULA MELT TRENDS

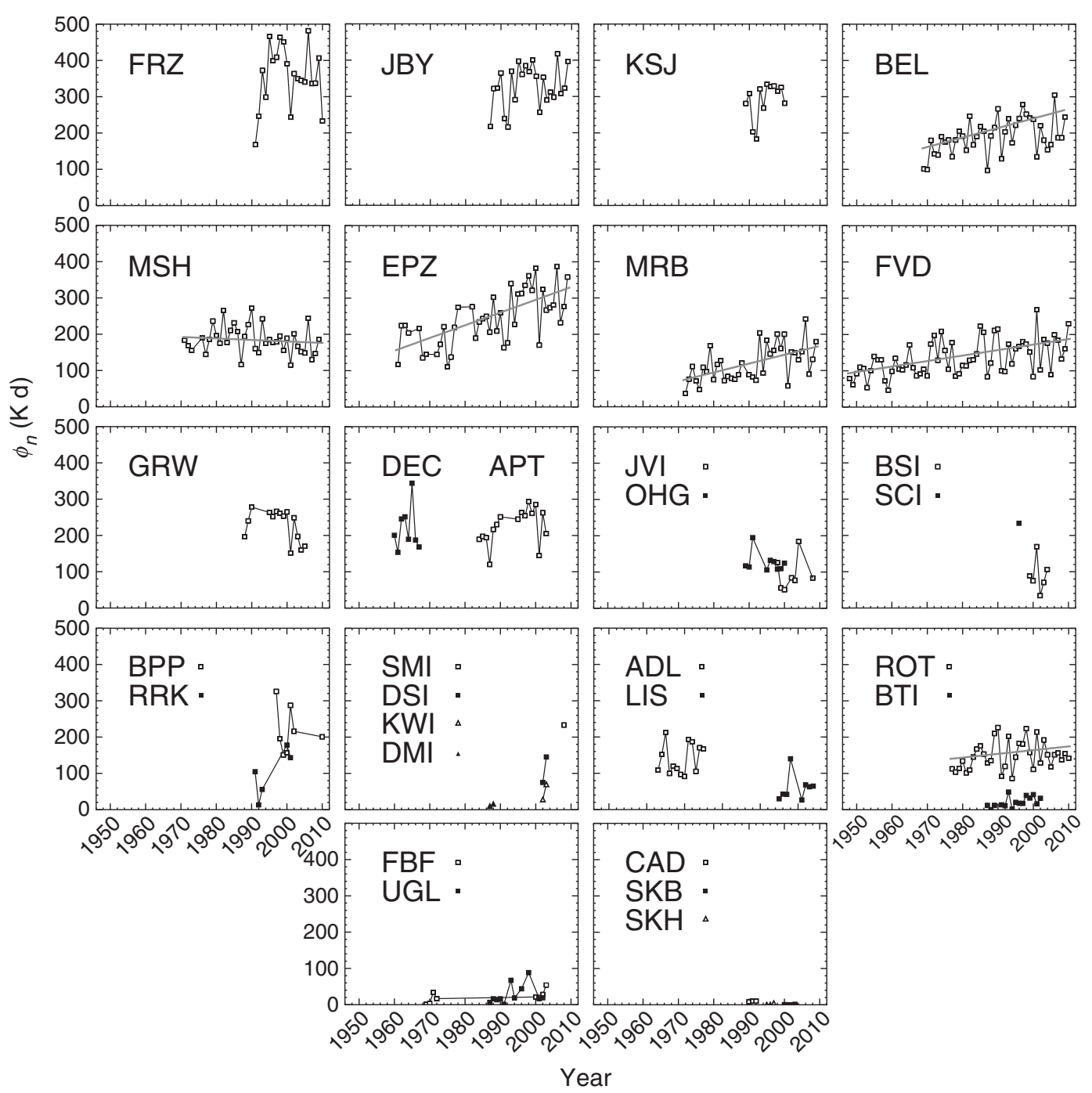

Figure 4. Annual positive degree day sums from Antarctic Peninsula station temperature records (see Figure 1 and Table 1 for location and description of climate stations). Trend lines are included on station records where time series were of sufficient length to derive long-term trends ( $>30$ years).

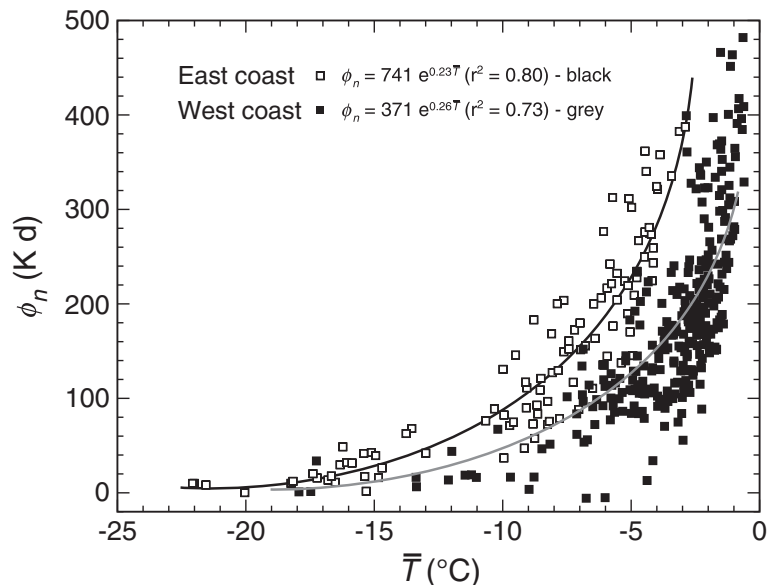

Figure 5. Correlation of positive degree day sums and mean annual air temperatures for station data on the East (open square) and West (filled square) coasts of the Antarctic Peninsula. meltwater volume using temperature index modelling approaches [e.g., Hock, 2005; Vaughan, 2006].

\subsection{Variability in Melt Onset From QSCAT Observations and Comparison With RACMO2 Simulations}

[20] Anomalies in satellite derived melt onset date (MOD), calculated by subtracting yearly MODs from the 2000-2009 mean, show large interannual variability yet no clear trend throughout the QSCAT era (Figure 6). Melt occurs almost everywhere on the AP on the islands and throughout Graham Land (north of $\sim 69^{\circ} \mathrm{S}$ ), and at elevations below $\sim 1000 \mathrm{~m}$ a.s.l. in Palmer Land (south of $69^{\circ} \mathrm{S}$ ) (Figures 6 and 7). On average, melt begins during early to mid-October (day of melt year (DOY) $275 \sim 290$ ) in the northern AP, South Shetland Islands, and on Wilkins ice shelf (Figure 7a). Along the grounded central spine of AP in Graham Land, melt onset occurs progressively later in the season, increasing with both latitude and elevation above sea level. Melt onset on islands along the west coast also appears to be strongly latitudinally controlled, with melt first occurring on Anvers Island 


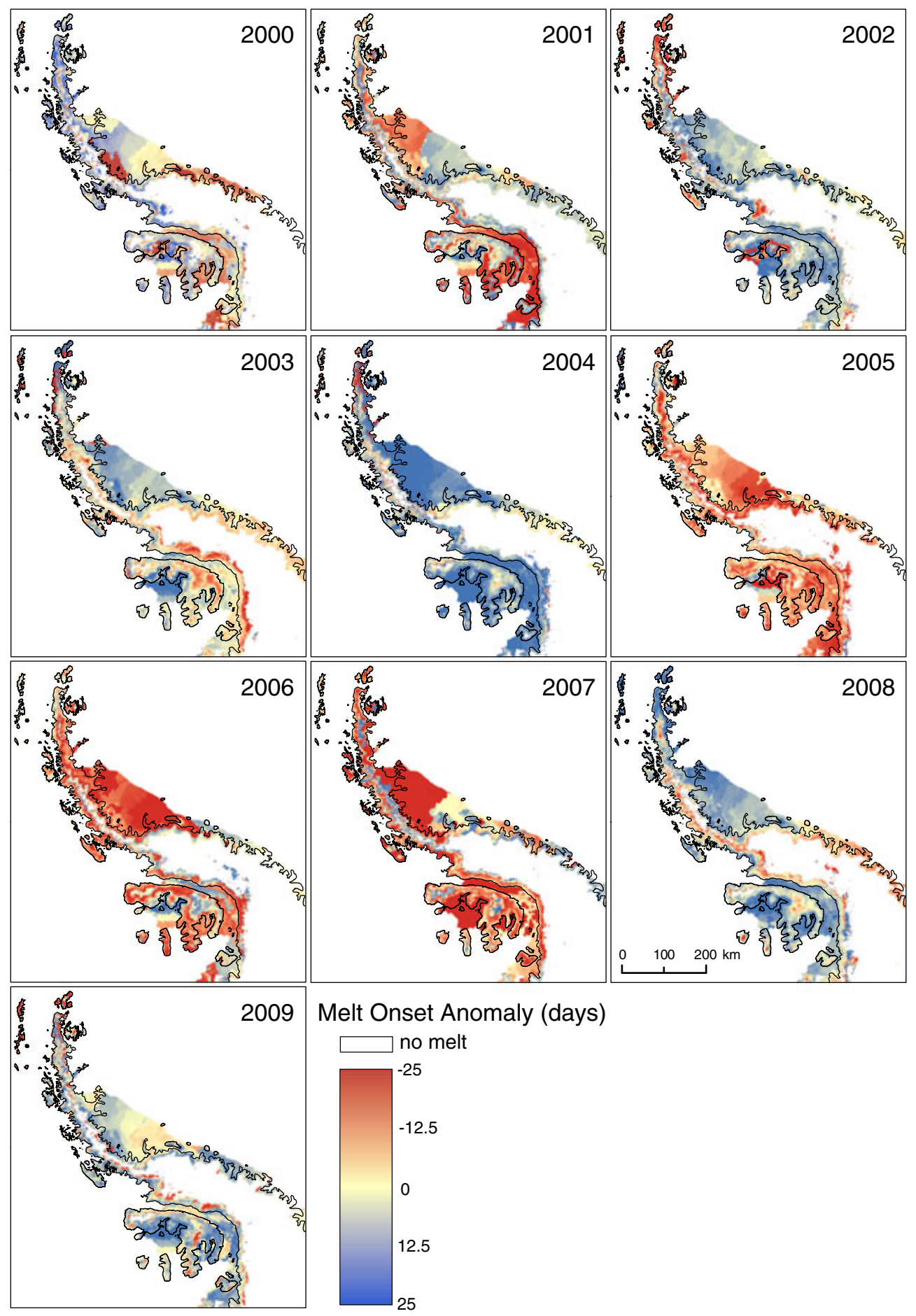

Figure 6. Annual maps of QSCAT-derived melt season onset date anomalies (number of days) on the Antarctic Peninsula, during 2000-2009. Outlines denote islands and the MOA grounded ice extent (Haran et al., 2006). Stark boundaries between MOD anomalies (for example, on Larsen C ice shelf in 2000, 2001, and 2007) result from the threshold approach to detecting melt. Melt seasons are labelled by their second year (i.e., summer 1999-2000 is 2000).

$\left(64.5^{\circ} \mathrm{S}\right.$ ) during early to mid-October (DOY $275 \sim 290$ ), Adelaide Island $\left(66.5 \sim 67.5^{\circ} \mathrm{S}\right)$ during mid to late-November (DOY $315 \sim 330)$, and Alexander Island $\left(69 \sim 72.5^{\circ} \mathrm{S}\right)$ between late-November to early-January (DOY $330 \sim 375$ ). The latest dates of melt onset (up to early-February, DOY
400) occur in the higher elevation, lower temperature regions of the interior ice cap. Among the major ice shelf systems, mean melt onset dates (MMODs) range from early to midOctober on Wilkins, early-November (DOY 310 320) on the remnant Larsen $\mathrm{B}$, northern Larsen $\mathrm{C}$, and northern 

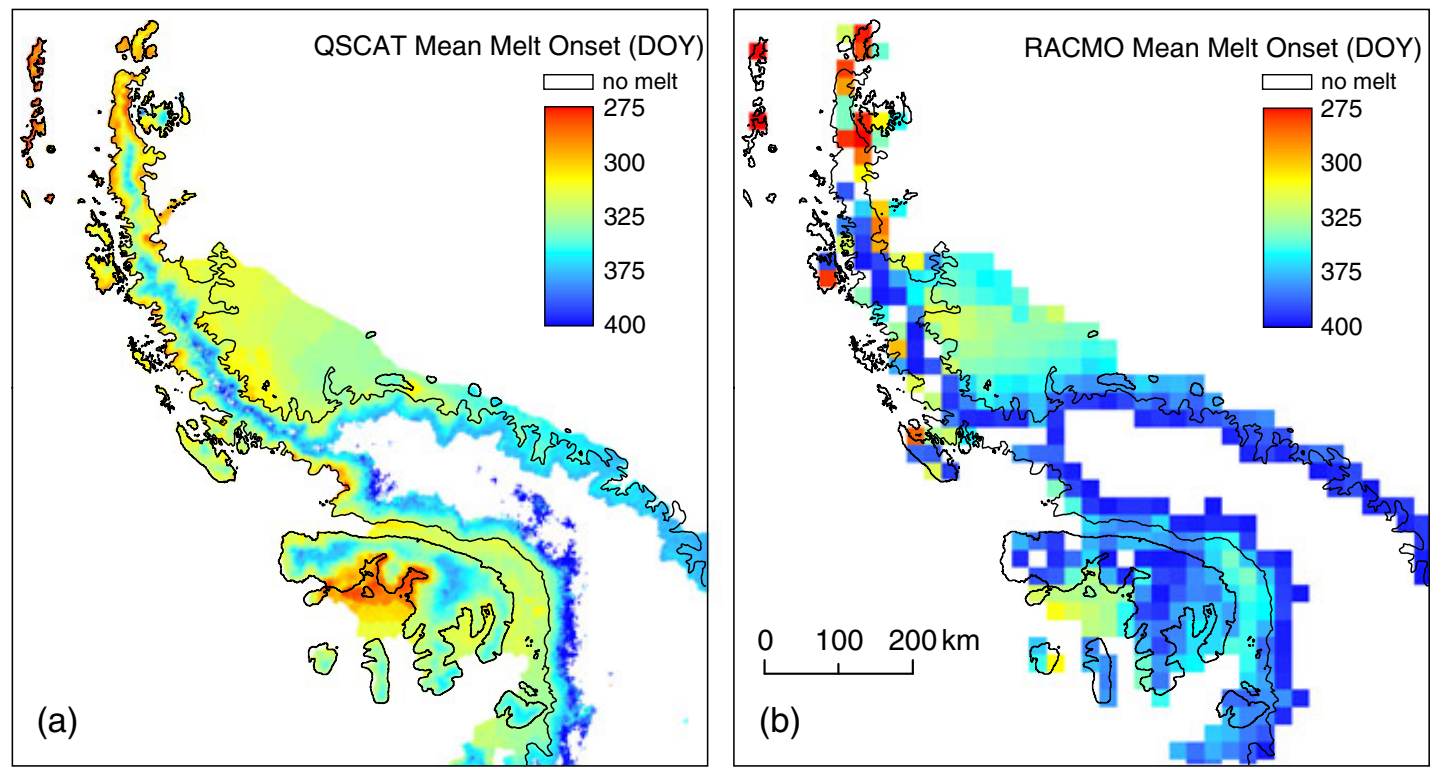

Figure 7. Mean MOD (day of melt season year) from (a) QSCAT observations, and (b) RACMO2 simulations, on the Antarctic Peninsula during 2000-2009.

George VI, and late-November to late-December (DOY 330 $\sim 360$ ) on the southern Larsen C, Larsen D, southern George VI and Stange (Figure 7, for locations see Figure 1).

[21] Variability in MOD was typically larger over ice shelves than grounded ice, examples include strongly positive anomalies on Larsen C and Wilkins in 2003, 2004, and 2008, and strongly negative anomalies in 2005, 2006, and 2007 (Figure 6). The increased variability in MOD over ice shelves may be due to the influence of ocean warming combined with greater variability in springtime weather at lower elevations. Although variability on land was typically less than on floating ice shelves, there was large interannual variability at the highest elevations of the AP ice sheet. This occurs as only the most intense melt events reach higher elevations and the timing of these events is likely to be highly variable. Mean melt onset date on the AP from QSCAT observations (1999-2009) was December 3rd (DOY 337). Averaged over the entire AP, 2007 had the earliest (20 November, DOY 324) and 2004 the latest (16 December, DOY 350) MMOD (Figure 11).

[22] While the presence of melt is defined slightly differently by our QSCAT and RACMO2 analyses, the good correspondence between satellite-derived melt and the main periods of observed positive air temperatures (e.g., Figure 3) (which are reproduced well by RACMO2 [Lenaerts et al., 2012] suggests that there should be good compatibility between both approaches. Comparison of MMOD from QSCAT observations and RACMO2 simulations confirms that both approaches identified 2007 as the year of earliest MMOD (20 November from QSCAT, and 24 November from RACMO2). The RACMO2 year of latest MMOD was 2003 (15 December), in contrast to the 2004 of QSCAT (16 December). On average, MMOD from RACMO2 simulations was 7 December, 4 days later than from QSCAT. This may indicate a greater sensitivity to melt in the scatterometer approach, or a cold-temperature or radiation bias in the RACMO2 simulations resulting from the choice of melt threshold.
[23] Examination of spatial trends in MMOD reveals that RACMO2 correctly reproduced the large-scale pattern of melt onset on the AP (Figure 7). Estimates of MMOD were most similar between satellite observations and RACMO2 simulations over the remnant Larsen B, northern Larsen C and Larsen D ice shelves, and the interior ice sheet in Palmer Land. For areas of the southern Larsen C, simulated MMOD occurred in late December, around a month later than in the satellite observations. Similarly, simulated MMOD on Wilkins and George VI ice shelves occurred in late November and mid to late December, respectively, up to a month later than in the satellite data. These differences may be attributable to a low elevation cold temperature bias in RACMO2 simulations, or the re-activation of persistent multi-year melt ponds on the surface of major ice shelves (particularly Wilkins and George VI, [e.g., Braun et al., 2009; Cook and Vaughan, 2010; Wager, 1972]) which are not resolved by RACMO2. In the case of George VI ice shelf, melt trends may additionally be affected by limited representation of atmospheric circulation in the $27 \mathrm{~km} \mathrm{RACMO} 2$ grid. The lack of wind tunnelling and fohn effects from either side of the shelf in RACMO2, combined with strong, subgrid-scale orographic effects on flow (turbulence), may act to underestimate melt.

[24] In Graham Land, RACMO2 simulated early October MMOD within coastal and island cells and late-January to early-February MMOD in the interior ice sheet. While these dates were consistent with satellite observations, melt was not simulated at all within some coastal and island grid cells. On islands where QSCAT detected extensive melt, RACMO2 identified melt within just a single grid cell (e.g., King George Island $\left(62^{\circ} \mathrm{S}, 58^{\circ} \mathrm{W}\right)$, Livingstone Island $\left.\left(62.5^{\circ} \mathrm{S}, 60^{\circ} \mathrm{W}\right)\right)$, or, in some cases, not at all (e.g., Brabant Island $\left(64.5^{\circ} \mathrm{S}\right.$, $\left.62.5^{\circ} \mathrm{W}\right)$, Renaud Island $\left(65.5^{\circ} \mathrm{S}, 66^{\circ} \mathrm{W}\right)$ ). This is likely due to the coarse $27 \mathrm{~km}$ model grid employed by RACMO2. The patchiness of RACMO2 melt extent in the interior of Graham Land may also be partly explained by the resolution of the 
model. The resolution of both RACMO2 and the digital elevation data available in this sector is likely too low to correctly represent the topography and atmospheric flow. Future RACMO2 simulations employing an improved, high-resolution surface model [Cook et al., 2012] may improve representation of melt in this region.

[25] Comparison of interannual variability in MOD during the QSCAT era was possible using three independent estimates of melting conditions (positive $T_{i}$ from station measurements, multi-day melt detection from QSCAT $\sigma^{0}$, and multi-day melt simulations from RACMO2). Time series of MOD were calculated for each melt season during the QSCAT era at the location of AP climate stations. MOD from station $T_{i}$ measurements was calculated as the DOY of the first above $0^{\circ} \mathrm{C}$ temperature, and for consistency with multi-day melt from QSCAT and RACMO2, periods of less than 3 consecutive days were removed from the records. QSCAT and RACMO2 data were extracted from the pixel coordinates containing each surface station and melt data were linearly interpolated from the nearest data pixel in instances where the station was located outside a data point. For comparison of $2.225 \mathrm{~km}$ resolution satellite data with $27 \mathrm{~km}$ resolution RACMO2 data, uncertainty was estimated for each QSCAT data point by calculating the standard deviation of MOD (in days) in a $12 \times 12$ window around each QSCAT pixel.
[26] The three approaches showed reasonable agreement at each of the $T_{i}$ station locations on the AP (Figure 8). Due to the nature of the comparison (point vs. $2.225 \mathrm{~km}$ QSCAT pixel vs. $27 \mathrm{~km}$ RACMO2 pixel), we may expect to see closer agreement between the two spatially averaged (pixel based) data sets. This is because point data from station measurements may be affected by their location on or close to rock outcrops, walls, open ocean, or other mixed terrain. No large biases were evident between MOD from RACMO2 and station or satellite observations. With some exceptions (RRK, BPP, BSI) interannual variability in MOD was well represented by RACMO2 simulations. At several locations (APT, JVI, FBF, UGL), MOD from all three approaches were very similar (within a week of one another). As the majority of climate stations and AWS are located close to sea level within the vicinity of the coast, some differences between observationally based estimates and model simulations may be expected due to the crude representation of coastal climate on the $27 \mathrm{~km}$ RACMO2 grid. However, both the magnitude and interannual variability of MOD from observations were mostly well represented by RACMO2, even at coastal stations.

[27] The three inland stations presented in Figure 8 (where edge effects of sea pixels at the resolution of the RACMO2 grid can be discounted; LIS, FBF, UGL) showed good

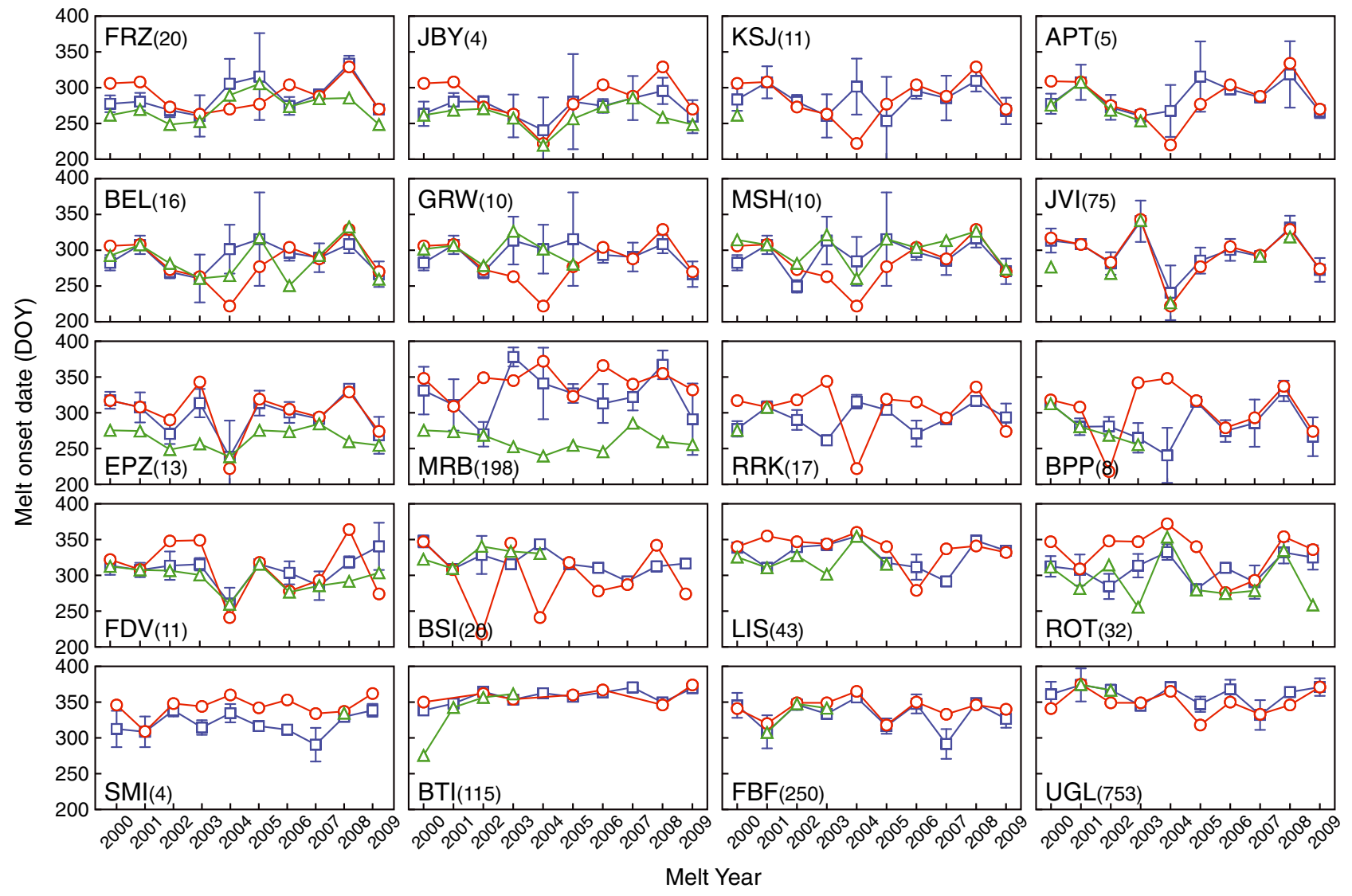

Figure 8. Time-series of MOD (DOY) for melt seasons during 2000-2009 at the location of each Antarctic Peninsula climate station (brackets after station identifier denote elevation in m.a.s.1). Green triangles represent MOD from station temperature data (where available), red circles from RACMO2 simulations at full model resolution $(27 \mathrm{~km})$, and blue squares from QSCAT observations $(2.225 \mathrm{~km}$ pixels). Gaps in station data appear where incomplete or no temperature observations were available. 


\section{BARRAND ET AL.: ANTARCTIC PENINSULA MELT TRENDS}

agreement between MOD from observations and simulations. At these three sites, the mean difference between QSCAT and RACMO2 MOD was -2 days $(\sigma=19)$, and between station temperature and RACMO2 MOD -14 days $(\sigma=18)$. Several other sites (for example, FRZ, EPZ, FDV) showed MOD from station temperature observations occurring earlier in the year than from satellite observations or
RACMO2 simulations. This may be due to the location of stations on mixed terrain or the presence of temperature inversions at the boundary layer. If $2-3 \mathrm{~m}$ air temperatures are higher than surface air temperatures, a $0^{\circ} \mathrm{C}$ melt threshold may result in earlier melt onset. Additionally, while coastal stations are typically located at or very close to sealevel, the $27 \mathrm{~km}$ RACMO2 grid will include elevations

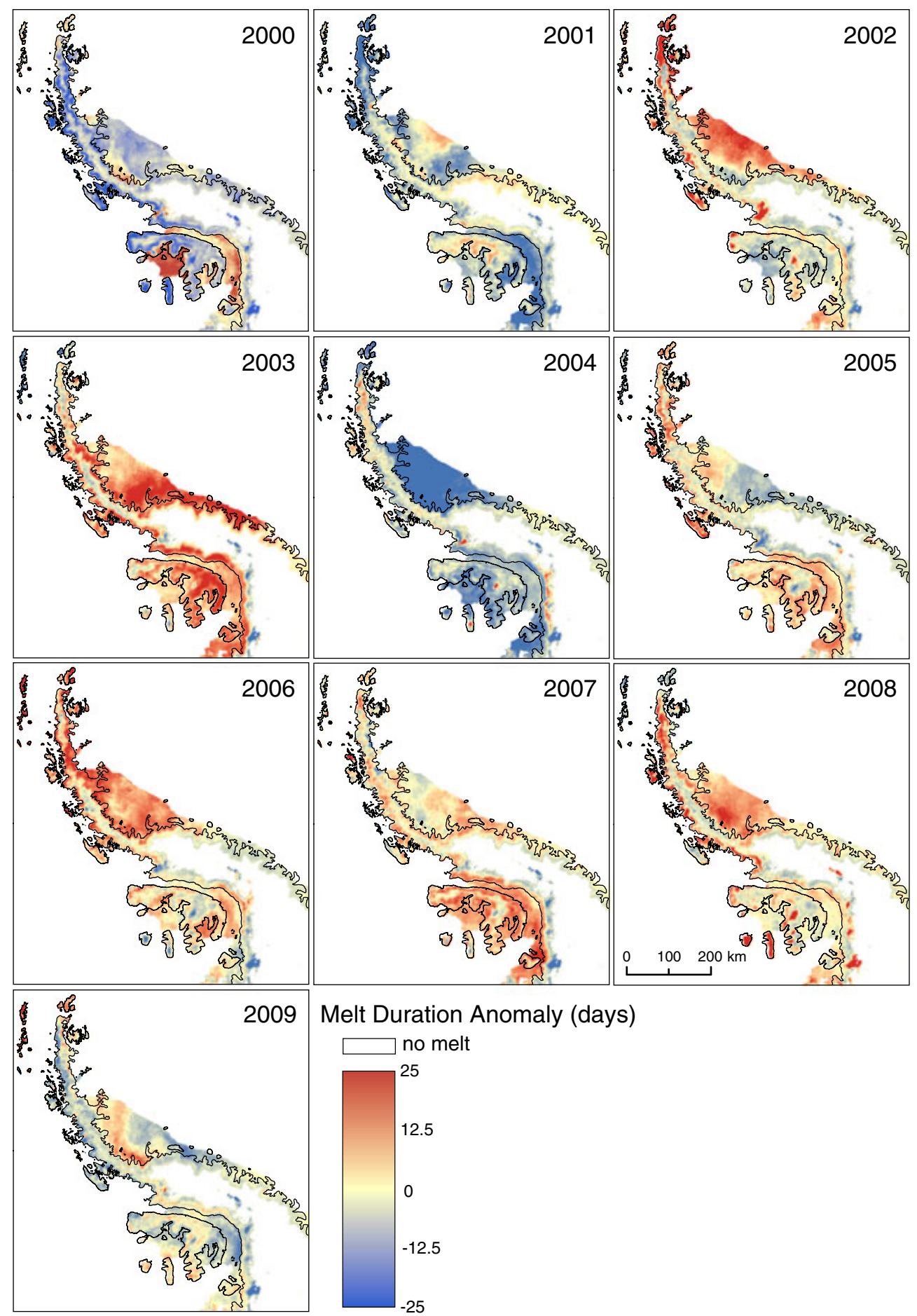

Figure 9. Annual maps of QSCAT-derived melt season duration anomalies (number of days) on the Antarctic Peninsula, during 2000-2009. Melt seasons are labeled by their second year (i.e., summer 1999-2000 is 2000). 
greater than this depending on local topography, a factor which will substantially impact the timing of melt onset.

\subsection{Variability in Melt Duration From QSCAT Observations and Comparison With RACMO2 Simulations}

[28] Similar to melt onset dates, anomalies in melt season duration (MD) from QSCAT data showed large interannual variability between 1999 and 2009 (Figure 9). Negative MD anomalies (shorter melt seasons) occurred throughout the coastal AP in 2000, in the northern AP and most of the ice shelves in 2001, and strongly throughout Larsen C, Wilkins and Stange ice shelves in 2004. Positive anomalies (longer melt seasons) occurred on Wilkins ice shelf in 2000, in the vicinity of Larsen B and Larsen C ice shelves during 2002, throughout the southern Larsen C and Larsen D ice shelves in 2003, and throughout Larsen C in 2006 and 2008 (Figure 9).

[29] The mean melt season duration (MMD) throughout AP during the QSCAT era was 49 days, with strongly negative MMDs in 2001 and 2004 (10 and 11 days below the decadal average, respectively), and the most positive MMDs during 2003, 2006, and 2008 (6, 7, and 5 days longer than average, respectively). The latest mean melt onset, in 2004 (16 December), coincided with the shortest MMD (38 days). Although the longest MMD in 2006 (55 days) did not coincide with the earliest melt season onset (which occurred in 2007), the 2006 melt season began 6 days earlier than the decadal mean. On average, the longest MMD ( $>110$ days) occurred on the South Shetland, d'Urville $\left(56^{\circ} \mathrm{W}, 63^{\circ} \mathrm{S}\right)$, and Renaud Islands, at low elevations on Anvers Island and on the west coast of Graham Land north of $\sim 65^{\circ} \mathrm{S}$ (Figure 10). MMD became progressively shorter inland and at higher elevations of both the interior ice sheet and the larger islands. MMD on Wilkins and the northern part of George VI ice shelf averaged 90-100 days, up to a month longer than the equivalent duration on islands and the grounded ice cap at similar latitudes. MMD throughout George VI ice shelf averaged between 70 and 90 days, in contrast to the 25-50 days

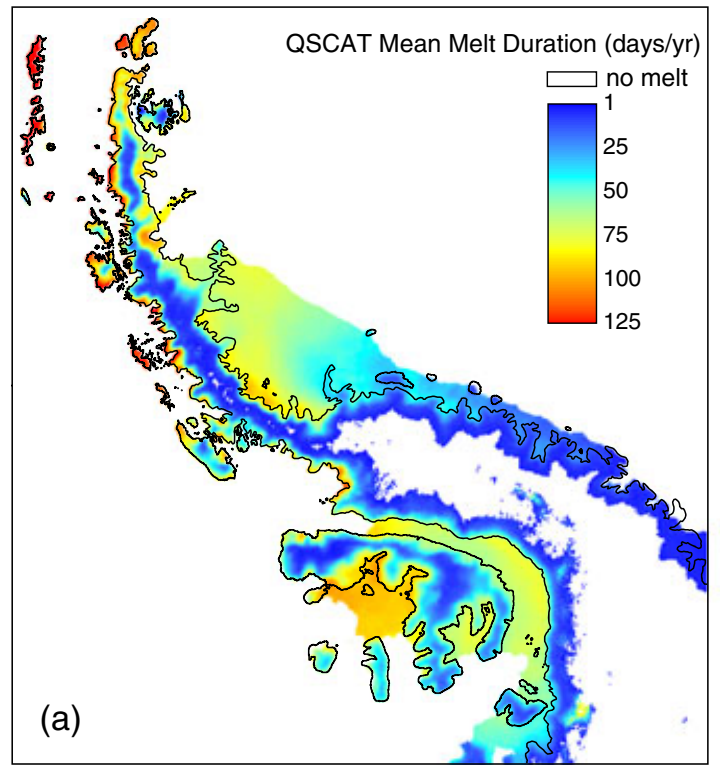

Figure 10. Mean melt duration (days/year) from (a) QSCAT observations, and (b) RACMO2 simulations, on the Antarctic Peninsula during 2000-2009.

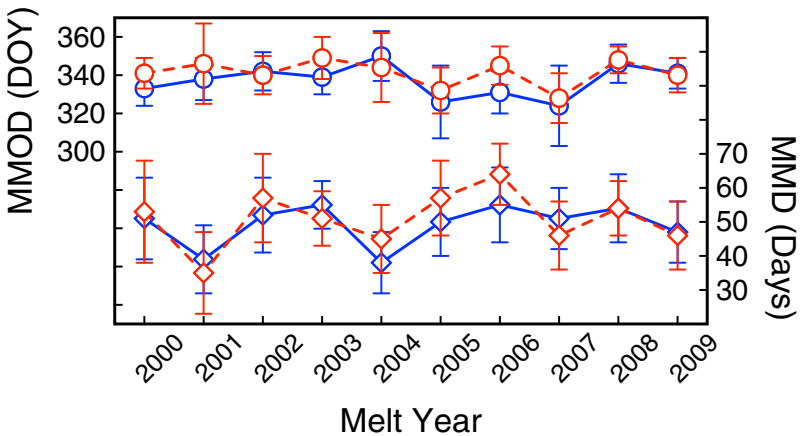

Figure 11. Antarctic Peninsula mean MOD (circles) and mean MD (diamonds) during 2000-2009 melt seasons, from QSCAT observations (blue solid line) and RACMO2 simulations (red dashed line). Measurement uncertainties resulting from spatial averaging are represented by the sample standard deviation ( $1 \sigma$ error bars).

on Alexander Island and the Rymil Coast, adjacent to George VI Sound. QSCAT observations reveal a strong latitudinal control on melt season duration across Larsen $\mathrm{C}$ ice shelf, with MMD of $\sim 25$ days in the vicinity of Hearst Island $\left(62^{\circ} \mathrm{W}, 69.5^{\circ} \mathrm{S}\right), \sim 50$ days at the centre of the ice-shelf, and $\sim 75$ days at Jason Peninsula at the northern extent of the shelf (Figure 10a). The high resolution of these data also reveal enhanced melt duration (80-90 days) along the Foyn and Bowman coasts at the landward margin of Larsen $\mathrm{C}$ ice shelf likely a result of advection of warmer maritime air masses into the leeward side of the orographic barrier of AP [Marshall et al., 2006; Orr et al., 2004].

[30] MMD averaged over the entire AP from RACMO2 simulations reproduced closely both the magnitude and interannual variability of QSCAT MMD (Figure 11). Average MMD throughout 2000-2009 was 51 days, just two days longer than the average MMD from QSCAT observations. The agreement between QSCAT and RACMO2 MMD reinforces the validity of the RACMO2 $0.4 \mathrm{~mm}$ melt detection threshold

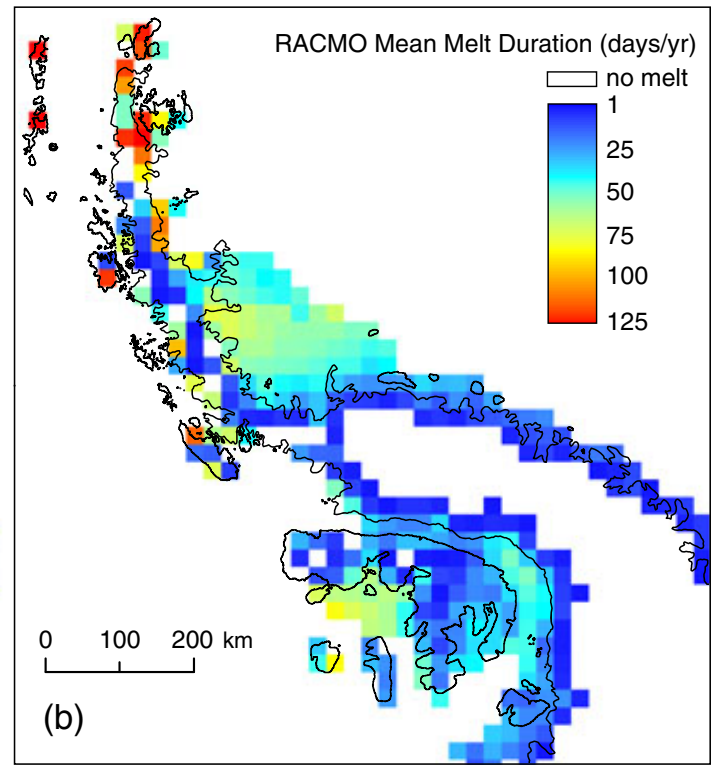


required for classifying melt days. Although RACMO2 identified 2001 as the shortest melt season (35 days), in contrast to 2004 from QSCAT (38 days), both approaches identified 2006 as the longest melt season (55 and 64 days, from QSCAT and RACMO2, respectively). RACMO2 also correctly reproduced the QSCAT regional-scale pattern of MMD throughout AP (Figure 10). Estimates of MMD were most similar between satellite observations and RACMO2 simulations in the interior of Palmer Land, in the interior of southern Graham Land, and on Alexander Island.

[31] On Larsen C, both satellite observations and RACMO2 simulations estimated MMD of $\sim 50$ days in the southern region of the ice shelf. While RACMO2 did not resolve the pattern of enhanced melt duration along the Foyn and Bowman coasts of the shelf (as observed by QSCAT), a general north-south gradient was evident, with MMD increasing to $\sim 75$ days toward Churchill Peninsula in the northwest sector of the shelf (Figure 10b). While MMD on Wilkins ice shelf (50-85 days) was longer than on the surrounding islands (typically up to $\sim 30$ days), this was shorter than that observed by QSCAT (90-100 days). Similarly, MMD on George VI ice shelf from RACMO2 (25-50 days) was also shorter than that observed by satellite data (7090 days). In the northern half of George VI Sound, the shelf is no wider than 1-2 RACMO2 grid cells, suggesting that coarse model resolution may at least partly explain this discrepancy between simulations and observations. However, the wider southern section of George VI Sound and Wilkins contain several ice shelf-only pixels, suggesting that underestimation of MMD in RACMO2 may have another origin. Both George VI and Wilkins are known to experience persistent multi-year seasonal surface melt ponds which are associated with zones of compressive stresses [Cook and Vaughan, 2010]. The early reactivation of these ponds at the onset of the melt season (section 3.3) will result in relatively longer MMDs when observed by QSCAT. In RACMO2, superfluous water produced at the surface does not pond but percolates into the firn which when saturated then runs off to the ocean. As surface melt ponds are not resolved by the physics or the resolution of the model, there is no albedo feedback from dark melt ponds, and no memory from recent years, melt season duration from RACMO2 may therefore be underestimated in these areas.

\subsection{QSCAT Melting Conditions and Ice Shelf Stability}

[32] Examining QSCAT melt onset anomalies in the context of ice-shelf retreat or breakup (major retreat or breakup events occurred on Wilkins in 2000, 2002-2004, 2008, and Larsen B in 2002) showed that MOD anomalies were largely positive on, or in the vicinity of, these shelves during each of these years (see Figure 6), suggesting no evident link between early melt season onset and ice-shelf retreat or breakup. This finding does not, however, discount the role of meltwater (inferred from longer melt season duration) in ice-shelf breakup. Documented retreats of Wilkins ice shelf in 2000 and 2008 [e.g., Braun et al., 2009; Cook and Vaughan, 2010] were coincident with strongly positive melt duration anomalies across the entire shelf in 2000 and on Charcot and Latady Islands adjacent to the shelf in 2008 (Figure 9). The catastrophic collapse of $\sim 3250 \mathrm{~km}^{2}$ of Larsen B ice-shelf in February 2002 also occurred during a melt season some 15-25 days longer than the 2000-2009

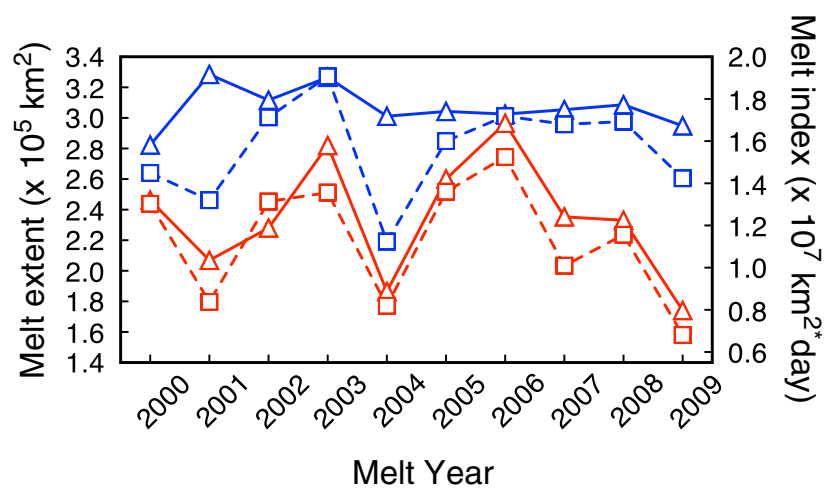

Figure 12. Antarctic Peninsula melt extent (solid line, triangles) and melt index (dashed line, squares) during 2000-2009 melt seasons, from QSCAT observations (blue) and RACMO2 simulations (red).

mean (as measured on the remnant sections of Larsen B, Jason Peninsula, and the northern sections of Larsen $\mathrm{C}$ ice shelf). These results are consistent with the findings of previous work linking break-up or retreat events with longer melt season durations [Scambos et al., 2000; van den Broeke, 2005] and suggesting crevasse propagation by meltwater as the main mechanism by which ice shelves may weaken and retreat.

\subsection{Variability in Melt Extent and Index}

[33] Interannual trends in AP melt extent and index from QSCAT observations and RACMO2 simulations are shown in Figure 12. During the QSCAT era, the largest melt season extent occurred during 2001, directly following the lowest melt year in 2000. Despite the collapse of Larsen B ice shelf in 2002, the subsequent melt season in 2003 extended just $0.02 \times 10^{5} \mathrm{~km}^{2}$ less than the 2001 maximum. Since 2003, melt extent has remained relatively stable at $\sim 3.0 \times 10^{5} \mathrm{~km}^{2}$, although 2009 experienced the lowest melt area since 2000 (Figure 12, blue triangles), consistent with the findings of Tedesco and Monaghan [2009]. Melt index on the AP was anticorrelated with melt extent during several years (for example, 2001 and 2004), suggesting that melt was less intensive over a greater area during these years (and, therefore, relatively more intensive over a smaller area, during 2000 and 2002). These results are consistent with those of Picard and Fily [2006] to 2005, and of Trusel et al. [2012], who also showed that the average melt index for AP is nearly equal to that of the remaining continent combined, even though its melt extent accounts for just one-fifth of the continental total. While our results are broadly similar to those of Trusel et al. [2012], there are small differences in interannual variability of both melt extent and index, likely due to our taking account of all major ice shelf area changes between 1999 and 2009. Additionally, magnitudes of AP melt extent and index calculated here are approximately $15 \%$ and $30 \%$ lower than the earlier study, respectively. This is likely due to their larger definition of AP which extends further south into Ellsworth Land and the Eltanin Bay catchment, and a slightly more sensitive $2 \mathrm{~dB}$ backscatter melt detection threshold. This lower $\sigma^{0}$ threshold requires a smaller reduction in backscatter for a day to be classified as melting and as such will result in relatively larger values of both melt extent and index. 
[34] Interannual variability in melt extent from RACMO2 simulations was similar to that from QSCAT observations, although years of high and low extent tended to be more pronounced in the RACMO2 data. Only in the 2001 and 2006 melt seasons were QSCAT and RACMO2 melt extents anticorrelated, with relatively high melt extent in 2001 from QSCAT and relatively low from RACMO2, and relatively low melt extent in 2006 from QSCAT and relatively high from RACMO2 (see Figure 12). Melt index from both approaches showed similar interannual variability and were reasonably well correlated $\left(\mathrm{r}^{2}=0.50, \mathrm{p}<0.005\right)$. The variations between QSCAT melt extent and index (e.g., the inverse relationship during the 2001 melt season) were typically either less well-pronounced or absent in the RACMO2 data. Between 2000 and 2009, RACMO2 melt extent and index were strongly correlated $\left(\mathrm{r}^{2}=0.86, \mathrm{p}<0.001\right)$. There was no such relationship between these variables in the QSCAT data $\left(\mathrm{r}^{2}=0.09, \mathrm{p}<0.001\right)$, although the correlation is improved when data from 2001 and 2004 are excluded $\left(\mathrm{r}^{2}=0.84, \mathrm{p}<0.001\right)$. This suggests that the coarser resolution RACMO2 simulations may not reproduce a full detailed picture of melting dynamics on the AP during high extent, low index (i.e., low duration) melt seasons.

\subsection{Relationships Between Melt Indices and Synoptic Variables}

[35] In order to understand the potential drivers of surface melt on the AP, melt indices (onset date, duration, extent, and index) were correlated with a range of regional- and synoptic-scale environmental and atmospheric variables. Previous research on melt trends throughout continental Antarctica has highlighted the importance of the SAM and the atmospheric component of the El-Niño Southern Oscillation (ENSO), the Southern Oscillation Index (SOI, the normalized difference in surface pressure between Tahiti and Darwin, Australia) [Tedesco and Monaghan, 2009; Torinesi et al., 2003; Trusel et al., 2012]. These large-scale modes of atmospheric variability impact climate in the high southern latitudes and have been shown to strongly influence near-surface air temperatures [Marshall et al., 2006; Turner, 2004]. Although surface snowmelt is not directly proportional to air temperature, previous research has identified strong and statistically significant correlations between negative melting anomalies in Antarctica (extent and index) and the combined positive phase anomalies of SAM and SOI between 1979-2009 [Tedesco and Monaghan, 2009], and between melt intensity and SAM and SAM + SOI for the period 1999 to 2009 [Trusel et al., 2012].

[36] Within the AP, [Tedesco and Monaghan [2009] calculated weak and statistically insignificant (at 5\% level) correlations between melt index and SAM and SOI, yet stronger and statistically significant correlations between melt extent and SAM, SOI, and SAM + SOI $(r=-0.52,-0.44$, and -0.54 , respectively). Consistent with these findings, we found correlations between 1999-2009 QSCAT AP melt index and individual and combined phase anomalies of the SAM [Marshall, 2003], SOI (esrl.noaa.gov/psd/data/correlation/ soi.data), and Nina3.4 (East Central Tropical Pacific sea surface temperatures, esrl.noaa.gov/psd/data/correlation/nina34. data) were weak and not significant at the 5\% level. Anti-correlation between QSCAT melt extent and the October, November, December, January (ONDJ) averaged
SAM index, however, was strong $(\mathrm{r}=-0.59, \mathrm{p}<0.05)$, as were both $\mathrm{SAM}+\mathrm{SOI}$ indices combined (multiple $\mathrm{r}=-0.55$, $\mathrm{p}<0.05$ ), and SAM + Nina3.4 combined (multiple $\mathrm{r}=-0.49$, $\mathrm{p}<0.05)$. These results therefore show that negative melting anomalies on the AP are strongly associated with the combined positive phase of SAM and ENSO indices during October-January throughout the QSCAT era, consistent with the findings of previous work. The finding that combined indices including SOI and Nina3.4 were less well correlated with AP melt extent than the SAM index alone (correlation between melt extent and SOI was also weak and insignificant at the 5\% level) may be attributable to the well-documented varying effects of ENSO on the AP [e.g., Trusel et al., 2012; Turner, 2004]. While the SOI / Nina3.4 components of ENSO might be expected to influence surface air temperatures in this region, the signal is frequently complicated by the non-linear response of sea-ice in the adjacent Bellingshausen Sea to oceanic and atmospheric warming [Turner, 2004].

[37] QSCAT melt indices were also correlated with nearsurface air temperatures, $10 \mathrm{~m}$ wind speeds, mean sea-level pressures from surface fields of the ERA-Interim reanalysis [Dee et al., 2011] and monthly sea-ice concentrations derived from SMMR and SSM/I satellite microwave data [Comiso, 1999]. Of these indices, only the November near-surface air temperature field showed a clearly defined and statistically significant correlation with MMOD (at the 5\% level). We acknowledge that a lack of additional correlations may be due to the short length of QSCAT time-series and that correlation of regionally-averaged indices does not allow examination of relationships between melt and environmental variables at local scales. November near-surface air temperatures and MMOD were strongly negatively correlated $(\mathrm{r}=<-0.6)$, indicating a clear link between atmospheric warming and the onset of the melt season in the AP.

\section{Summary and Conclusions}

[38] Trends in surface melting conditions on the AP were analysed using in situ meteorological observations, spaceborne scatterometer data, and output from simulations of a state-of-the-art regional climate model. Multi-decadal time series trends in the duration of melting (above-freezing) conditions, extended in length and to include previously unavailable station records, revealed large positive trends at most but not all $>30$ year station records, including a near-doubling (95\% increase) of annual average PDD sums since 1948 at Faraday/Vernadsky station. Trends were strongly positive and statistically significant at Bellingshausen, Esperanza, Marambio, and Faraday/Vernadsky, although at Bellingshausen and Rothera stations PDD sums were below the long-term mean during seven cooler than average years since 2004. Long time series trends were strongly correlated between stations on either side of AP, indicating that these trends are likely to be pervasive throughout the northern AP (Graham Land).

[39] Analysis of enhanced resolution scatterometer data from the SeaWinds instrument onboard QSCAT provided high-resolution spatially representative melt climatologies of the AP between 1999 and 2009. Melt onset maps revealed that the melt season began earliest in the South Shetland Islands, northern AP and Wilkins ice-shelf and were used to link melt season onset with November near-surface air 
temperatures. While melt was typically more variable over ice shelves than grounded ice, no evident link was identified between early melt season onset and ice shelf retreat or breakup events. However, consistent with the findings of previous research, ice-shelf break-up or retreat events were found to coincide with longer melt season durations. These high-resolution melt climatologies may be used in combination with analyses of ice shelf areal extent, surface elevation, and firn-air content [e.g., Cook and Vaughan, 2010; Fricker and Padman, 2012; Holland et al., 2011] to examine ice shelf sensitivity to environmental and physical factors.

[40] QSCAT melt extent in the AP was shown to be strongly correlated with the October-January averaged SAM index, linking AP melt trends to large-scale (global) modes of atmospheric variability. This identification of linkages between melting conditions and the SAM, from more spatially representative data, provides further support for studies associating long-term atmospheric warming from climate station data with trends in the summer SAM index [e.g., Marshall et al., 2006]. Extension of the scatterometer time-series using Oceansat-2 and ASCAT data may permit calculation of temporal trends in melt indices and stronger correlations between atmospheric variables.

[41] Comparison of melt indices derived from in situ and spaceborne observations with output from simulations of the regional model RACMO2 showed that despite issues related to model resolution $\mathrm{RACMO} 2$ accurately reproduced the spatial pattern, magnitude and interannual variability of melt onset and duration on the AP. Local discrepancies in melt season duration were observed between QSCAT observations and RACMO2 simulations, in particular over northern parts of Graham Land and George VI and Wilkins ice shelves. These were likely due to crude representation of climate on the $27 \mathrm{~km}$ RACMO2 grid in the coastal and complicated terrain of the northern Peninsula and differences between QSCAT response to, and RACMO2 treatment of, ponded water on ice shelves. While RACMO2 does not currently resolve meltwater ponds (excess meltwater is not ponded but rather runs off to the ocean), planned future runs at higher spatial resolutions and utilising improved digital elevation data sets in the northern Peninsula are likely to further improve model performance in this region.

[42] Acknowledgments. This work was supported by funding from the ice2sea programme from the European Union 7th Framework Programme, grant 226375, and by NSF grant ANT 1141973. Ice2sea contribution 082 . We thank the associate editor Jeremy Bassis and three anonymous reviewers for comments which improved the manuscript.

\section{References}

Ashcraft, I., and D. Long (2006), Comparison of methods for melt detection over Greenland using active and passive microwave measurements, Int. J. Remote Sensing, 27(12-14), 2469-2488,doi:10.1080/01431160500534.

Braun, M., A. Humbert, and A. Moll (2009), Changes of Wilkins Ice Shelf over the past 15 years and inferences on its stability, Cryosphere, 3, 41-56.

Brown, R., and P. Mote (2009), The response of Northern Hemisphere snow cover to a changing climate, J. Clim., 22, 2124-214, doi: 10.1175/ JCLI2665.1.

Comiso, J. (1999), it Bootstrap sea ice concentrations from Nimbus-7 SMMR and DMSP SSM/I, version 2 (1999-2009), Digital Media, Natl. Snow and Ice Data Cent., Boulder, Colo. [updated 2012].

Cook, A., and D. Vaughan (2010), Overview of areal changes of the ice shelves on the Antarctic Peninsula over the past 50 years, Cryosphere, 4, 77-98.

Cook, A., T. Murray, A. Luckman, D. Vaughan, and N. Barrand (2012), A new 100-m digital elevation model of the Antarctic Peninsula derived from ASTER Global DEM: methods and accuracy assessment, Earth Syst. Sci. Data Discuss., 5, 365-403, doi:10.5194/essdd-5-365-2012.

De Angelis, H., and P. Skvarca (2003), Glacier surge after ice shelf collapse, Science, 299, 1560-1562.

Dee, D. P., et al. (2011), The ERA-Interim reanalysis: configuration and performance of the data assimilation system, Q. J. R. Meteorol. Soc., 137(656), 553-597, doi:10.1002/qj.828.

Early, D., and D. Long (2001), Image reconstruction and enhanced resolution imaging from irregular samples, IEEE Trans. Geosci. Remote Sensing, 39(2), 291-302.

Ettema, J., M. van den Broeke, E. van Meijgaard, W. van de Berg, J. Box, and K. Steffen (2010), Climate of the Greenland ice sheet using a highresolution climate model- Part 1: Evaluation, Cryosphere, 4, 511-527, doi: $10.5194 /$ tc $-4-511-2010$

Fahnestock, M., W. Abdalati, and C. Shuman (2002), Long melt seasons on ice shelves of the Antarctic Peninsula: An analysis using satellite-based microwave emission measurements, Ann. Glaciol., 34 (1), 127-133.

Fricker, H., and L. Padman (2012), Thirty years of elevation change on Antarctic Peninsula ice shelves from multimission satellite radar altimetry, J. Geophys. Res., 117, C02026, doi:10.1029/2011JC007126.

Haran, T., J. Bohlander, T. Scambos, T. Painter, and M. Fahnestock (2006), MODIS mosaic of Antarctica (MOA) image map, Digital Media.

Helsen, M., M. van den Broeke, R. van der Wal, W. van de Berg, E. van Meijgaard, C. Davis, Y. Li, and I. Goodwin (2008), Elevation changes in Antarctica mainly determined by accumulation variability, Science, 320, 1626-1629, doi:10.1126/science.1153,894.

Hock, R. (2005), Glacier melt: A review of processes and their modelling, Prog. Phys. Geogr., 29(3), 362-391.

Hock, R., M. de Woul, V. Radić, and M. Dyurgerov (2009), Mountain glaciers and ice caps around Antarctica make a large sea-level rise contribution, Geophys. Res. Lett., 36, L07501, doi:10.1029/2008GL037020.

Holland, P., H. Corr, H. Pritchard, D. Vaughan, R. Arthern, A. Jenkins, and M. Tedesco (2011), The air content of Larsen ice shelf, Geophys. Res. Lett., 38, L10503, doi:10.1029/2011GL047245.

Intergovernmental Panel on Climate Change (2007), Climate Change 2007: The Physical Science Basis. Contribution of Working Group I to the Fourth Assessment Report of the Intergovernmental Panel on Climate Change, in Climate Change 2007: The Physical Science Basis. Contribution of Working Group I to the Fourth Assessment Report of the Intergovernmental Panel on Climate Change, edited by S. Solomon et al., Cambridge Univ. Press, New York.

Ivins, E., M. Watkins, D. Yuan, R. Dietrich, G. Casassa, and A. Rulke (2011), On-land ice loss and glacial isostatic adjustment at the Drake Passage: 2003-2009, J. Geophys. Res., 116, B02403, doi:10.1029/2010JB007607.

Jonsell, U., F. Navarro, M. Banon, J. Lapazaran, and J. Otero (2012), Sensitivity of a distributed temperature-radiation index melt model based on AWS observations and surface energy balance fluxes, Hurd Peninsula glaciers, Livingston Island, Antarctica, Cryosphere, 6, 539-552, doi:10.5194/tc-6-539-2012.

Kuipers Munneke, P., G. Picard, M. van den Broeke, J. Lenaerts, and E. van Meijgaard (2012a), Insignificant change in Antarctic snowmelt volume since 1979, Geophys. Res. Lett., 39, L01501, doi:10.1029/ 2011 GL050207.

Kuipers Munneke, P., M. van den Broeke, J. King, T. Gray, and C. Reijmer (2012b), Near-surface climate and surface energy budget of Larsen $C$ ice shelf, Antarctic Peninsula, Cryosphere, 6, 353-363, doi:10.5194/tc-6353-2012.

Kuipers Munneke, P., M. van den Broeke, J. Lenaerts, M. Flanner, A. Gardner, and W. van de Berg (2011), A new albedo parameterization for use in climate models over the Antarctic ice sheet, J. Geophys. Res., 116, D05114, doi:10.1029/2011JD015113.

Kunz, L., and D. Long (2006), Melt detection in Antarctic ice shelves using scatterometers and microwave radiometers, IEEE Trans. Geosci. Remote Sensing, 44(9), 2461-2468.

Lenaerts, J., M. van den Broeke, W. van de Berg, E. van Meijgaard, and P. K. Munneke (2012), A new, high-resolution surface mass balance map of Antarctica (1979-2010) based on regional atmospheric climate modeling, Geophys. Res. Lett., 39, L04501, doi:10.1029/2011GL050713.

Li, J., H. Zwally, and J. Comiso (2007), Ice-sheet elevation changes caused by variations of the firn compaction rate induced by satellite-observed temperature variations (1982-2003), Ann. Glaciol., 46, 8-13.

Ligtenberg, S., M. Helsen, and M. van den Broeke (2011), An improved semi-empirical model for the densification of Antarctic firn, Cryosphere, 5, 809-819, doi:10.5194/tc-5-809-2011.

Long, D., and B. Hicks (2010), Standard BYU QuikSCAT and Seawinds land/ice image products, revision 3.1, technical report, Brigham Young Univ., Provo, Utah.

Machguth, H., F. Paul, S. Kotlarski, and M. Hoelzle (2009), Calculating distributed glacier mass balance for the Swiss Alps from regional climate model 


\section{BARRAND ET AL.: ANTARCTIC PENINSULA MELT TRENDS}

output: A methodical description and interpretation of the results, J. Geophys. Res., 114, D19106, doi:10.1029/2009JD011775.

Marshall, G. (2003), Trends in the Southern Annular Mode from observations and reanalysis, J. Clim., 16, 4134-4143.

Marshall, G., A. Orr, N. van Lipzig, and J. King (2006), The impact of a changing Southern Hemisphere Annular Mode on Antarctic Peninsula summer temperatures, J. Clim., 19, 5388-5404.

Meredith, M., and J. King (2005), Rapid climate change in the ocean west of the Antarctic Peninsula during the second half of the 20th century, Geophys. Res. Lett., 32, L19604, doi:10.1029/2005GL024042.

Nghiem, S., K. Steffen, R. Kwok, and W. Tsai (2001), Detection of snowmelt regions on the Greenland ice sheet using diurnal backscatter change, J. Glaciol., 47, 539-547.

Ohmura, A. (2001), Physical basis for the temperature-based melt-index method, J. Appl. Meteorol., 40, 753-761.

Orr, A., D. Cresswell, G. Marshall, J. Hunt, J. Sommeria, C. Wang, and M Light (2004), A "low-level" explanation for the recent large warming trend over the western Antarctic Peninsula involving blocked winds and changes in zonal circulation, Geophys. Res. Lett., 31, L06204, doi:10.1029/2003GL019160.

Picard, G., and M. Fily (2006), Surface melting observations in Antarctica by microwave radiometers: Correcting 26-year time series from changes in acquisition hours, Remote Sensing Environ., 104, 325-336.

Picard, G., M. Fily, and H. Gallee (2007), Surface melting derived from microwave radiometers: A climatic indicator in Antarctica, Ann. Glaciol. 49, 29-34.

Radic, V., and R. Hock (2006), Modeling future glacier mass balance and volume changes using ERA-40 reanalysis and climate models: A sensitivity study at Storglaciaren, Sweden, J. Geophys. Res., 111, F03003, doi:10.1029/ 2005JF000440.

Radic, V., and R. Hock (2011), Regionally differentiated contribution of mountain glaciers and ice caps to future sea-level rise, Nat. Geosci., 4, 91-94, doi:10.1038/NGEO1052.

Ridley, J. (1993), Surface melting on Antarctic Peninsula ice shelves detected by passive microwave sensors, Geophys. Res. Lett., 20, 2639-2642.

Rignot, E., J. Bamber, M. van den Broeke, C. Davis, Y. Li, W. van de Berg, and E. van Meijgaard (2008), Recent Antarctic ice mass loss from radar interferometry and regional climate modelling, Nat. Geosci., 1, 106-110.

Rignot, E., G. Casassa, P. Gogineni, W. Krabill, A. Rivera, and R. Thomas (2004), Accelerated ice discharge from the Antarctic Peninsula following the collapse of the Larsen B ice shelf, Geophys. Res. Lett., 31, L18401, doi:10.1029/2004GL020697.

Robertson, R., M. Visbeck, A. Gordon, and E. Fahrback (2002), Long-term temperature trends in the deep waters of the Weddell Sea, Deep Sea Res. Part II, 49(21), 4791-4806.

Roesch, A. (2006), Evaluation of surface albedo and snow cover in AR4 coupled climate models, J. Geophys. Res., 111, D15111, doi:10.1029/2005JD006473.

Rotschky, G., T. Schuler, J. Haarpaintner, J. Kohler, and E. Isaksson (2011), Spatio-temporal variability of snowmelt across Svalbard during the period 2000-08 derived from quikscat/seawinds scatterometry, Polar Res., 30, 5963.

Rott, H., F. Muller, T. Nagler, and D. Floricioiu (2011), The imbalance of glaciers after disintegration of Larsen-B ice shelf, Antarctic Peninsula, Cryosphere, 5, 125-134.

Rott, H., K. Sturm, and H. Miller (1993), Active and passive microwave signatures of Antarctic firn by means of field measurements and satellite data, Ann. Glaciol., 17, 337-343.

Rückamp, M., M. Braun, S. Suckro, and N. Blindow (2011), Observed glacial changes on the King George Island ice cap, Antarctica, in the last decade, Global Planet. Change, 79, 99-109, doi:10.1016/j.gloplacha.2011.06.009.

Santer, B., T. Wigley, J. Boyle, D. Gaffen, J. Hnilo, D. Nychka, D. Parker, and K. Taylor (2000), Statistical significance of trends and trend differences in layer-average atmospheric temperature time series, J. Geophys. Res., 105(D6), 7337-7356.

Scambos, T., J. Bohlander, C. Shuman, and P. Skvarca (2004), Glacier acceleration and thinning after ice shelf collapse in the Larsen B embayment, Antarctica, Geophys. Res. Lett., 31, L18402, doi:10.1029/2004GL020670.

Scambos, T., C. Hulbe, M. Fahnestock, and J. Bohlander (2000), The link between climate warming and break-up of ice shelves in the Antarctic Peninsula, J. Glaciol., 46, 516-530.

Sharp, M., and L. Wang (2009), A five-year record of summer melt on Eurasian Arctic ice caps, J. Clim., 22, 133-145.

Shuman, C., E. Berthier, and T. Scambos (2011), 2001-2009 elevation and mass losses in the Larsen A and B embayments, Antarctic Peninsula, J. Glaciol., 57(204), 737-754.
Smith, R., and S. Stammerjohn (2001), Variations of surface air temperature and sea-ice extent in the western Antarctic Peninsula region, Ann. Glaciol., 33, 493-500.

Smith, A., D. Vaughan, C. Doake, and A. Johnson (1998), Surface lowering of the ice ramp at Rothera Point, Antarctic Peninsula, in response to regional climate change, Ann. Glaciol., 27, 113-118.

Stammerjohn, S., D. Martinson, R. Smith, X. Yuan, and D. Rind (2008), Trends in Antarctic annual sea-ice retreat and advance and their relation to El Niño-Southern Oscillation and Southern Annular Mode variability, J. Geophys. Res., 113, C03S90, doi:10.1029/2007JC004269.

Steig, E., D. Schneider, S. Rutherford, M. Mann, J. Comiso, and D. Shindell (2009), Warming of the Antarctic ice-sheet surface since the 1957 International Geophysical Year, Nature, 457, doi:10.1038/nature07669.

Steiner, N. (2012), The remote sensing and measurement of polar melt processes, PhD dissertation, Graduate Cent., City Univ. N. Y., New York.

Tedesco, M. (2009), Assessment and development of snowmelt retrieval algorithms over Antarctica from K-band spaceborne brightness temperature (1979-2008), Remote Sensing Environ., 113, 979-997.

Tedesco, M., and A. Monaghan (2009), An updated Antarctic melt record through 2009 and its linkages to high-latitude and tropical climate variability, Geophys. Res. Lett., 36, L18502, doi:10.1029/2009GL039186.

Tedesco, M., W. Abdalati, and H. Zwally (2007), Persistent surface snowmelt over Antarctica (1987â€“"-2006) from 19.35 GHz brightness temperatures, Geophys. Res. Lett., 34, L18504, doi:10.1029/2007GL031199.

Thomas, E., G. Marshall, and J. McConnell (2008), A doubling in snow accumulation in the western Antarctic Peninsula since 1850, Geophys. Res. Lett., 35, L01706, doi:10.1029/2007GL032529.

Torinesi, O., M. Fily, and C. Genthon (2003), Variability and trends of the summer melt period of Antarctic ice margins since 1980 from microwave sensors, J. Clim., 16, 1047-1060.

Trusel, L., K. Frey, and S. Das (2012), Antarctic surface melting dynamics: Enhanced perspectives from radar scatterometer data, J. Geophys. Res. 117, F02023, doi:10.1029/2011JF002126.

Turner, J. (2004), The El Niño Southern Oscillation and Antarctica, Int. J. Climatol., 24, 1-31.

Turner, J., S. Colwell, and S. Harangozo (1997), Variability of precipitation over the coastal western Antarctic Peninsula from synoptic observations, J. Geophys. Res., 102(D12), 13,999-14,007.

Turner, J., S. Colwell, G. Marshall, T. Lachlan-Cope, A. Carleton, P. Jones, V. Lagun, P. Reid, and S. Iagovkina (2005), Antarctic climate change during the last 50 years, Int. J. Climatol., 25, 279-294.

Ulaby, F., R. Moore, and A. Fung (1986), Microwave Remote Sensing: Active and Passive, Volume 1: Fundamentals and Radiometry, Artech House, Boston, Mass.

Van de Wal, R., and M. Wild (2001), Modelling the response of glaciers to climate change by applying volume-area scaling in combination with a high resolution GCM, Clim. Dyn., 326, 984-986.

van den Broeke, M. (2005), Strong surface melting preceded collapse of Antarctic Peninsula ice shelf, Geophys. Res. Lett., 32, L12815, doi:10.1029/2005GL023247.

van den Broeke, M., W. van de Berg, and E. von Meijgaard (2006), Snowfall in coastal West Antarctica much greater than previously assumed, Geophys. Res. Lett., 33, L02505, doi:10.1029/2005GL025239.

Vaughan, D. (2006), Recent trends in melting conditions on the Antarctic Peninsula and their implications for ice-sheet mass balance and sea level, Arct. Antarct. Alp. Res., 38(1), 147-152.

Vaughan, D., G. Marshall, W. Connelley, C. Parkinson, R. Mulvaney, D. Hodgson, J. King, C. Pudsey, and J. Turner (2003), Recent rapid regional climate warming on the Antarctic Peninsula, Clim. Change, $60,243-274$

Wager, A. (1972), Flooding of the ice shelf in George VI Sound, Br. Antarct. Surv. Bull., 28, 71-74.

Wang, L., M. Sharp, B. Rivard, S. Marshall, and D. Burgess (2005), Melt season duration on Canadian Arctic ice caps, 2000-2004, Geophys. Res. Lett., 32, L19502, doi:10.1029/2005GL023962.

Wang, L., M. Sharp, B. Rivard, and K. Steffen (2007), Melt season duration and ice layer formation on the Greenland ice sheet, 2000-2004, J. Geophys. Res., 112, F04013, doi:10.1029/2007JF000760.

Zhang, J., U. Bhatt, W. Tangborn, and C. Lingle (2007), Climate downscaling for estimating glacier mass balances in northwestern North America: Validation with a USGS benchmark glacier, Geophys. Res. Lett., 34 L21505, doi:10.1029/2007GL031139.

Zwally, H., and S. Fiegles (1994), Extent and duration of Antarctic surface melting, J. Glaciol., 40(136), 463-476. 